NBER WORKING PAPER SERIES

\title{
LONGER-RUN EFFECTS OF ANTI-POVERTY POLICIES ON DISADVANTAGED NEIGHBORHOODS
}

\author{
David Neumark \\ Brian J. Asquith \\ Brittany Bass \\ Working Paper 25231 \\ http://www.nber.org/papers/w25231 \\ NATIONAL BUREAU OF ECONOMIC RESEARCH \\ 1050 Massachusetts Avenue \\ Cambridge, MA 02138 \\ November 2018
}

We thank the Laura and John Arnold Foundation and the Employment Policies Institute for support for this research. Asquith gratefully acknowledges funding from the Alfred P. Sloan Foundation (grant G-2017-9813) and the National Bureau of Economic Research (NBER). Any opinions or conclusions expressed are the authors' own and do not necessarily reflect those of the Laura and John Arnold Foundation, Employment Policies Institute, the Sloan Foundation, or the NBER. The funders have had no control over the content or conclusions of this research. We received helpful comments from Matt Freedman, Hilary Hoynes, Joe Sabia, and from seminar/ conference participants at Bar Ilan University, DIW-Berlin, Hebrew University, IZA, the Melbourne Institute, Nanyang Technical University, the National Tax Association Annual Conference, the National University of Singapore, the Norwegian School of Economics, Singapore Management University, the Tinbergen Institute, Tulane, UC-Berkeley, UCI, Université Catholique de Louvain, and the University of Sydney. We are grateful for helpful research assistance from Luis Munguia Corella. The views expressed herein are those of the authors and do not necessarily reflect the views of the National Bureau of Economic Research.

NBER working papers are circulated for discussion and comment purposes. They have not been peer-reviewed or been subject to the review by the NBER Board of Directors that accompanies official NBER publications.

(C) 2018 by David Neumark, Brian J. Asquith, and Brittany Bass. All rights reserved. Short sections of text, not to exceed two paragraphs, may be quoted without explicit permission provided that full credit, including $(\subset$ notice, is given to the source. 
Longer-Run Effects of Anti-Poverty Policies on Disadvantaged Neighborhoods

David Neumark, Brian J. Asquith, and Brittany Bass

NBER Working Paper No. 25231

November 2018

JEL No. I38,J18,J2

\begin{abstract}
$\underline{\text { ABSTRACT }}$
We estimate the longer-run effects of minimum wages, the Earned Income Tax Credit, and welfare on key economic indicators of economic self-sufficiency in disadvantaged neighborhoods. Our strongest findings are twofold. First, the longer-run effects of the EITC are to increase employment and to reduce poverty and public assistance, as long as we rely on national as well as state variation in EITC policy. Second, tighter welfare time limits also reduce poverty and public assistance in the longer run; while the effect on public assistance result may be mechanically related to loss of benefits, the effect on poverty is more likely behavioral. It is harder to draw firm conclusions about minimum wages and welfare benefits. With some specifications and samples, the evidence suggests that higher minimum wages lead to longer-run declines in poverty and the share of families on public assistance, whereas higher welfare benefits have adverse longer-run effects. However, the evidence on minimum wages and welfare benefits is not robust - and the estimated effects of minimum wages are sometimes in the opposite direction, including when we restrict the analysis to more recent data that is likely of more interest to policymakers.
\end{abstract}

David Neumark

Department of Economics University of California, Irvine

3151 Social Science Plaza

Irvine, CA 92697

and NBER

dneumark@uci.edu

Brian J. Asquith

W.E. Upjohn Institute

300 S Westnedge Ave

Kalamazoo, MI 49007

basquith86@gmail.com
Brittany Bass

Department of Economics

University of California at Irvine

3151 Social Science Plaza

Irvine, CA 92697

bassb@uci.edu 


\section{Introduction}

The long-running research and policy debates about anti-poverty policies have two important shortcomings that we seek to begin to rectify in this paper. First, they have tended to focus on short-term effects, rather than asking how these policies have affected income, and economic self-sufficiency more generally, in the longer run. Second, they have largely ignored “place,” focusing on program effects on individuals and their families, without asking whether these policies have succeeded in lifting the economic fortunes of particularly disadvantaged areas.

We counter these shortcomings, in studying the effects of the main anti-poverty policies in the United States that attempt to increase income from work, or that substitute for income from work and hence might strongly affect work incentives - minimum wages, the Earned Income Tax Credit, and welfare. We estimate the longer-run effects of these policies on measures of economic self-sufficiency - most importantly, poverty and receipt of public assistance - and focus on their effects in neighborhoods that are initially disadvantaged. The underlying potential mechanism we have in mind for differing longer-run effects of these policies is that policies that encourage more work over time will lead to greater accumulation of human capital, and hence higher wages and earnings.

Most research on minimum wages focuses on the short-term employment effects of minimum wages - typically for teenagers (see the review in Neumark and Wascher, 2007) and more recently for other low-wage workers, like restaurant workers (e.g., Dube et al., 2010). This evidence tells us little or nothing about whether minimum wages reduce poverty even in the short term, although that question has begun to get more attention (e.g., Dube, 2017; Sabia and Burkhauser, 2010). Virtually no work has studied the longer-run effects of minimum wages, with three exceptions: indirect evidence on training (or education), which could affect earnings in the longer term (e.g., Acemoglu and Pischke, 2003); research directly estimating the 
effects on adult earnings of exposure to a higher minimum wage as a teenager (Neumark and Nizalova, 2007); and more recent work by Clemens and Wither (2016) reporting that binding minimum wage increases during the Great Recession period lowered the income growth of affected workers.

Research on the Earned Income Tax Credit (EITC) has also focused on short-run employment effects (e.g., Meyer, 2010), although some work studies the effects of the EITC on poverty (e.g., Neumark and Wascher, 2011). There are some exceptions, mostly in very recent work. Dahl et al. (2009) examine longer-term effects of the EITC via work incentives, estimating the impacts of a major federal expansion of the EITC on individual women's earnings up to five years later. ${ }^{1}$ More recently, Neumark and Shirley (2017) adopt a longer-run perspective, studying the effects of exposure to a more generous EITC over women’s 20s and 30s on subsequent wages and earnings. And taking an inter-generational perspective, Bastian and Michelmore (forthcoming) estimate the effect of exposure in childhood on adult outcomes, finding positive employment and earnings effects; they suggest that these results are driven by labor supply (and hence earnings) impacts on parents.

The EITC is sometimes viewed as a more effective policy than the minimum wage to increase income from work, in large part because it incentivizes work. This question can be revisited in the longer-run perspective we adopt in this paper, recognizing the possibility that the EITC could also have limited effectiveness in economically-disadvantaged areas if there are not employment opportunities to be taken advantage of by those induced to look for work by a more generous EITC.

Finally, the literature on welfare is extensive, and has focused on both employment effects (e.g., Grogger, 2003) and distributional effects (e.g., Bitler et al., 2006). Again, there is

\footnotetext{
${ }^{1}$ Card and Hyslop (2005) study longer-term effects of a similar program in Canada. There is also some research tying the EITC to longer-term outcomes via effects on children. For a review of related work, see Neumark (2016).
} 
very little work on longer-run effects, although Grogger (2009) and Hotz et al. (2006) study whether welfare programs that encouraged employment (and in the latter case, training) boosted longer-run earnings. Moreover, the question has been raised of whether welfare generates longer-run dependency on government programs (e.g., Murray, 1983).

The existing research on these anti-poverty policies has focused nearly exclusively on their effects on individuals or families, and not on effects on areas of concentrated disadvantage or poverty. Perhaps the only exception (also a short-term analysis) is Thompson (2009), who shows that federal minimum wage increases in the mid-1990s had more adverse effects on teen employment in counties where minimum wages were more binding because of lower market wages. Our paper goes well beyond Thompson’s analysis - studying a much longer time horizon (1970-2010), including outcomes across all age ranges, and using a more disaggregated level of geography (the Census tract) that better isolates disadvantaged neighborhoods. The question of whether anti-poverty policies are beneficial or detrimental in helping to lift the economic fortunes of particularly disadvantaged areas is important, given that there is scant evidence that explicit place-based anti-poverty programs, such as enterprise zones, increase jobs or reduce poverty in disadvantaged neighborhoods. ${ }^{2}$

Geographically-concentrated poverty poses its own challenges above and beyond individual poverty, perhaps most importantly for minorities, who tend to cluster residentially in poor areas. ${ }^{3}$ Moreover, research suggests that living in poverty areas creates extra hardships for the poor and also for the non-poor residing in those areas, owing to less private-sector

\footnotetext{
${ }^{2}$ See, e.g., Neumark and Simpson (2015) and Neumark and Young (2017). The latter paper does not examine longer-run effects of explicit place-based policies, although research on this topic is in progress (Neumark and Young, in progress).

${ }^{3}$ American Community Survey (ACS) data from 2010 indicate that 50.4 percent of blacks, 44.1 percent of Hispanics, but only 20.3 percent of whites, reside in areas where the poverty rate is 20 percent or higher (see Bishaw, 2014, for more descriptive evidence). At the same time, poverty rate differences between these groups are much smaller (see https://www.census.gov/prod/2013pubs/acsbr11-17.pdf, viewed March 31, 2017).
} 
investment, higher crime, weaker labor market networks, poor health, etc. ${ }^{4}$ Thus, if antipoverty policies inadvertently lead to greater poverty in areas of concentrated poverty, their adverse consequences may be exacerbated, extending beyond those who are directly affected. Conversely, policies that are help disadvantaged areas may have important short- and long-term positive spillovers, as effects from disadvantaged neighborhoods can have lasting impacts on the next generation (Chetty et al., 2014).

This paper is distinguished by a number of features. First, we simultaneously examine the effects of multiple anti-poverty policies, which provides direct comparisons of their effects and ensures that we do not spuriously attribute the effects of one policy to the effects of others. Second, we estimate policy effects on disadvantaged areas. And third, we look at longer-run effects, with a sample covering many decades.

To briefly summarize the results, our strongest findings are twofold. First, the longerrun effects of the EITC are to increase employment and to reduce poverty and public assistance, as long as we rely on national as well as state variation in EITC policy. Second, tighter welfare time limits also reduce poverty and public assistance in the longer run; while the effect on public assistance result may be mechanically related to loss of benefits, the effect on poverty is more likely behavioral. We also find some evidence that higher minimum wages, in the longer run, lead to declines in poverty and the share of families on public assistance, whereas higher welfare benefits have adverse longer-run effects, although the evidence on minimum wages and welfare benefits is not robust to using only more recent data, nor to some other changes. ${ }^{5}$

We want to be clear, at the outset, that identifying longer-run effects of policy especially multiple policies - is a challenge. We may rarely, if ever, have the kinds of

\footnotetext{
${ }^{4}$ See the summary of the evidence in Federal Reserve System and Brookings Institution (2008).

${ }^{5}$ Note that the evidence on welfare benefits does not imply that more generous welfare benefits do not help recipients, but rather that more generous benefits may reduce the extent to which these recipients become economically self-sufficient.
} 
compelling identification strategies sometimes available to study the short-term effects of a single policy. In contrast, the most feasible and convincing approach may be what we have done in this paper - combining differencing strategies with a detailed look at potential threats to identification, and at the sensitivity of the conclusions to sensible alterations in the sample, the specification, etc. Nonetheless, even if one remains cautious about a causal interpretation of our findings, the longer-term relationships we document provide interesting suggestive evidence about the likely effects of alternative anti-poverty policies in the longer-run.

\section{Research Strategy}

Our econometric strategy is to use long-term panel data to estimate longer-run effects of anti-poverty policies on economic outcomes in Census tracts that are initially disadvantaged, relative to other tracts. ${ }^{6}$ To explain the approach, denote tracts by $c$, states by $s$, counties by $j$, and years by $t$. Denote by $Y_{c s t}$ our economic outcomes variables; we focus on the poverty rate and the share of households on public assistance, but study other outcomes as well. ${ }^{7}$ Denote by $P_{c s t}$ a vector of policies that can vary by state and year. And denote by $D I S^{b}{ }_{c}$ a measure of initial disadvantage defined at the tract level; $D I S^{b}{ }_{c}$ is a dummy variable indicating that a tract was in the top quartile of a measure of socioeconomic disadvantage (i.e., the mostdisadvantaged quartile) in the baseline period $(b)$.

As control variables, we also include Census tract fixed effects $\left(C T_{c}\right)$, to account for

\footnotetext{
${ }^{6}$ It would clearly also be interesting to estimate longer-run effects of anti-poverty policies on people or families. There are not many data sets with which to do this, however, since the most compelling analyses requires longterm longitudinal data, as well as data covering many cohorts so that there is policy variation (ruling out the National Longitudinal Surveys). As noted earlier, Neumark and Shirley (2017) estimate the long-term effects of exposure to a more generous EITC, using the PSID. With the Census data we use in this present paper, we can track areas over time (indeed, many decades), but not people.

${ }^{7}$ Aside from policy concerns, our focus on poverty and public assistance is motivated by data limitations. As discussed below, the data we use provide tract-level aggregates. Although we also estimate effects on average earnings and employment rate measures, we cannot, for example, estimate effects on earnings and employment of separate groups (such as single mothers) to better understand the estimated effects on family level outcomes such as poverty. In current work using microdata (Neumark et al., in progress), we can do more to unpack the effects on these outcomes on subgroups.
} 
time-invariant heterogeneity across Census tracts. We also include a full set of interactions between county dummy variables $\left(C O_{j}\right)$ and year fixed effects $\left(Y R_{t}\right)$. These interactions control very flexibly for local shocks to economic outcomes that could potentially be correlated with the policy variables. We cannot, of course, include tract-by-year interactions because these would capture all of the variation in the dependent variables.

We also always include a control for the effects on tracts of long-term changes in the structure of jobs in the aggregate economy. ${ }^{8}$ We use the approach, originating with Bartik (1991), of applying national time-series changes in aggregated sectoral employment to the tract or other subareas, based on the tract's or subarea's sectoral composition in the baseline period. While it is most natural to think of this in terms of industry, in the Neighborhood Change Database (NCDB) we use, we can only do this for occupation. ${ }^{9}$ To define this control variable, let subscript $k$ index occupations. Denote by $S E_{c s k b}$ total employment in tract $c$, state $s$, occupation $k$, and baseline period $b$, denote by $A E_{k t}$ aggregate (national) employment in each period $t$ in occupation $k$, and denote by $A E_{k b}$ aggregate employment in occupation $k$ in the baseline period $b$. Then tract (or subarea) employment based solely on aggregate developments is predicted in each period after $b$ by applying the national changes to the baseline composition, as in

$$
P S E_{c s t}=\sum_{k} S E_{c s k b} \times\left(\frac{A E_{k t}-A E_{k b}}{A E_{k b}}\right) \cdot 10
$$

For our baseline analyses, we extract from the NCDB measures of $Y$ for 1980, 1990,

\footnotetext{
${ }^{8}$ For example, it is widely agreed that declines in manufacturing hit narrow areas where manufacturing was concentrated (think the South Side of Chicago, or Flint, Michigan), as highlighted in the seminal work of Wilson (1990) or Autor et al. (2013).

${ }^{9}$ The NCDB data does not provide tract-level information on the number of persons working in a specific industry. Instead, it includes employment in nine categories of occupations (for persons 16+): professional and technical occupations; executives, managers, and administrators; sales; administrative support and clerical; precision production, craft, and repair; operators, assemblers, transportation, and materials; nonfarm laborers; service; and farm workers or in forestry and fishing.

${ }^{10}$ This control is entered in logs because the level can differ so much across tracts.
} 
2000, and 2010, and measures of $D I S^{b}$ for $1970 .{ }^{11}$ We specify our model to estimate the longerrun impacts of the anti-poverty policies in $P$ on initially disadvantaged tracts relative to other tracts. The model we estimate is

$$
Y_{c s t}=\alpha+\left\{D I S^{b} c_{c} \cdot P_{c s t}\right\} \cdot \beta+\left\{D I S^{b} \cdot P_{c s, t-10}\right\} \cdot \beta^{\mathrm{L}}+C T_{c^{\prime}} \cdot \delta^{\prime}+\left\{C O_{j} \cdot Y R_{t}\right\} \cdot \omega+\theta \cdot \ln \left(P S E_{c s t}\right)+\varepsilon_{c s t} .
$$

In equation (2), the parameters $\beta$ and $\beta^{\mathrm{L}}$ capture the contemporaneous and 10-year lag effect of the policies in $P$. The main effects of policy variation on non-disadvantaged tracts (with $D I S^{b}=0$ ) are subsumed in the county-by-year fixed effects, since policy generally varies at the state level (and very slightly at the county level). ${ }^{12,13}$ The estimates of $\beta$ and $\beta^{\mathrm{L}}$ capture the relative change in $Y$ in disadvantaged tracts, versus more-advantaged tracts, that are associated with the policy variation $P$.

Considered this way, $\beta$ and $\beta^{\mathrm{L}}$ are akin to triple-difference estimators. A basic tripledifference specification (ignoring the minor county variation in welfare benefits) would include main effects of the policy variables (not interacted with the indicator for disadvantaged tracts), year fixed effects, state fixed effects, the indicator for disadvantaged tracts, and interactions between this indicator and the year and state fixed effects. Many of these are subsumed in the richer control variables in equation (2). Specifically, including the county-by-year fixed effects subsumes main policy effects, and the tract fixed effects subsume the indicator for disadvantaged tracts as well as the interactions between this indicator and state fixed effects. The model would still include the year-by-disadvantaged tract interactions, which would imply

\footnotetext{
${ }^{11}$ DIS can be measured for later years, but we work with 1970 as our baseline in almost all of our analyses. As explained in the data section below, the 2010 measures are actually 2006-2010 measures based on the ACS. ${ }^{12}$ Welfare benefits have a limited degree of within-state variation, by county.

${ }^{13}$ The inclusion of the county-by-year interactions and the focus on estimating the effects on most-disadvantaged tracts is related to recent work on the identification of minimum wage effects (Dube et al., 2010; Allegretto et al., 2011; Neumark et al., 2014). This work highlights the question of whether region-specific economic shocks are correlated with minimum wage changes. However, when the county-by-year interactions are included, identification of $\beta$ and $\beta^{\mathrm{L}}$ comes solely from within-county and year variation, and the bias from potential correlations between state-level or county-level economic conditions and the (possibly endogenous) variation in minimum wages or other policies at the state or county level is eliminated.
} 
that the effects of policy are identified only from state-level variation; for example, differential effects of federal EITC variation in disadvantaged relative to advantaged areas, common to all states, would be absorbed in these interactions. It turns out, however - as we show later - that the estimated effects of the EITC are extremely imprecise when we include the year-bydisadvantaged tract interactions, owing to relatively little state variation. Hence, our main estimates do not include these interactions, and rely on federal as well as state EITC variation. ${ }^{14}$ However, the inclusion of the county-by-year interactions controls for geographic heterogeneity in shocks at a very granular level.

Aside from the controls we have discussed, the main model we use is parsimonious. It does not control for other characteristics of the population that may have changed over time (such as educational levels), because skill levels may be endogenous (e.g., Agell and Lommerud, 1997), or there may be differential migration responses to policy in more- versus less-disadvantaged areas. The exclusion of these compositional changes is appropriate in estimating policy impacts on places. Nonetheless, we also present estimates of models that allow for compositional shifts from migration, and find that the results are robust.

Naturally, to assess the robustness of our results and to gauge potential sources of bias, we also estimate other variants of our specification. We discuss these modifications of our analysis in the empirical section of the paper.

\section{Data}

\section{Neighborhood Change Database}

Our data on economic outcomes and other measures by tract come from the NCDB, ${ }^{15}$

\footnotetext{
14 The key papers in the EITC literature - establishing positive employment effects of low-skilled mothers - also use federal variation (Eissa and Liebman, 1996; and Meyer and Rosenbaum, 2001). The same is true of the longerterm analyses discussed in the Introduction.

${ }^{15}$ For a description of the data, see http://www.geolytics.com/USCensus,Neighborhood-Change-Database-19702000,Products.asp (viewed February 13, 2017).
} 
which provides tract-level aggregates on the key outcomes we study - earnings, employment, poverty, and public assistance. Importantly, the NCDB provides consistent tract definitions over time. In particular, it includes historical tract populations, demographic, and socioeconomic characteristics in 2010 Census tract geography, providing consistent longitudinal measures of these variables. ${ }^{16}$ However, because we estimate effects over many decades, based on characteristics of tract residents in a much earlier period (using 1970 as our baseline period to define $D I S^{b}$ ), we are restricted in the set of tracts we can use. ${ }^{17}$

The NCDB includes data from the 1970, 1980, 1990, and 2000 Census, and from the five-year rollups of the 2006-2010 ACS (which we sometimes refer to as “2010”). ${ }^{18}$ The NCDB excludes some variables otherwise publicly available from the Census (in the "Summary Files”), such as crosstabs on education by employment status by age group. However, these crosstabs were not published by the Census for 1970, and the age ranges that are reported change in each Census wave, making reconciling them longitudinally difficult. Thus, the NCDB remains the best public dataset for this analysis. ${ }^{19}$

\footnotetext{
${ }^{16}$ The NCDB-reported counts are reallocations of the Census' reported counts that use a combined area and population approach. Areal weights are determined from publicly available maps for all recent Census geography so that it is possible to calculate the area overlay between tracts in different Census years. To account for the uneven distribution of population within a tract, the NCDB exploits sub-tract geographic units, called Census blocks, which first exist nationwide in the 1990 Census. Census blocks are not standardized by population, but their decennial population counts are known and Census block boundaries never cross tract boundaries within the same Census year. These Census blocks form the basis for more precisely mapping populations across Census years and then aggregating the results to the tract level. More details on how the population reapportionment occurred at finer geographic levels and was then reconciled across Census waves can be found in Tatian et al. (2003).

${ }^{17}$ The Census first fully tracted the nation in 2000 (Krieger, 2006). In 1990, the Census had tracts in all 50 states plus Puerto Rico and U.S. outlying territories, but had only fully tracted six states: California, Connecticut, Delaware, Hawaii, New Jersey, and Rhode Island. Prior to that, Census tracts were only drawn for large cities (U.S. Department of Commerce, Bureau of the Census, 1994).

${ }^{18}$ Specifically, the 1970 data come from the Fourth Count Summary Tape for Population and Housing; the 1980 and 1990 data come from the Summary Tape Files 3A of their respective years; the 2000 data come from the Summary File 3A and Summary File 1; and the 2010 data come from the Summary File 1.

${ }^{19}$ One key advantage of using the NCDB data is that the data are publicly available, and the analysis therefore can be replicated and explored further by other researchers. The minimum wage literature, in particular, is replete with exchanges, comments, and replications of the work of others, and in our view these exchanges and sharing of data have been a critical part of the research endeavor and central to the high level of transparency to which researchers on all sides of the minimum wage debate have contributed. Thus, we did not simply want to do this research using confidential individual-level data with tracts identified - especially given that we are estimating and reporting on
} 
The longer-run perspective of our project makes it useful to have data covering many decades, and our specifications include 10-year lags, so that the first sample year we can use with the NCDB is 1980 . Although some of the relevant policy variation goes back to before 1940 (the minimum wage was created by the Fair Labor Standards Act in 1938), Census tracts can only be identified in a small subset of areas for 1940 and $1950 .{ }^{20}$ Thus, only beginning in 1960 can one use any Census data at the tract level to obtain a comprehensive look at the U.S. as a whole, but to date, the 1960 Census is not included in the NCDB.

With regard to the policies we study, the inability to use the earlier years is not much of a disadvantage. Most of the variation in the federal minimum wage, and all of the variation in state minimum wages, occurred much later - most federal variation after 1960, and state variation beginning in the late 1980s, and coverage of workers by the federal minimum wage was not very broad until the beginning of the $1960 \mathrm{~s} .{ }^{21}$ The other policies we study arise and begin to vary later - welfare in the 1960s and again with welfare reform in the 1990s, and the EITC at the federal level in the 1970s and at the state level in the 1980s. Thus, the constraint of starting our analysis is 1980 (with $D I S^{b}$ measured in 1970) is not too limiting.

Anti-Poverty Policies

We study the effects of minimum wages, the EITC, and welfare. ${ }^{22}$ We view these three

very different types of analyses than what has been done in past research.

${ }^{20}$ Census tract coverage and publicly available information prior to 1960 is limited. Only 45 cities were consistently given Census tracts before 1960 (Bogue, 2000a, 2000b, 2000c).

${ }^{21}$ See http://www.dol.gov/whd/minwage/coverage.htm (viewed February 13, 2015) and http://www.dol.gov/whd/minwage/chart.htm (viewed February 13, 2015).

${ }^{22}$ Two relatively major programs we do not consider are the Supplemental Nutrition Assistance Program (SNAP, previously Food Stamps), or the Child and Dependent Care Tax Credit (CCTC). For SNAP/Food Stamp benefit levels, only Alaska and Hawaii differ from federal guidelines. Prior to July 1, 1974, there was some spatial variation through rollouts of when Food Stamps became active, although most urbanized, predominantly lowincome, and high black share counties had the program by 1970 (Almond et al., 2011), which again severely limits variation in SNAP/Food Stamp benefits (in this case based on rollout). Since welfare reform in the 1990s, SNAP/Food Stamps has had work, search, or training requirements, and hence potentially affects work incentives through those mechanisms, although limited research suggests it does not, but is instead largely a supplement to wages (for those able to work); see Rosenbaum (2013) and Moffitt (2015). The CCTC is a non-refundable credit, unlike the EITC, and hence is thought to provide weak benefits to low-income families for whom the question of 
policies as the intersection of the policies most central to anti-poverty efforts, and the policies most likely to affect income and work.

Information on state minimum wages from 1983-2014 was taken from the data used in Neumark et al. (2014). We extended the data back to 1960 relying on Quester (1980) and Sutch (2010), ${ }^{23}$ also cross-referencing dates and levels against state and federal sources. ${ }^{24}$ We code the minimum wage as the higher of the state or federal minimum wage, as is standard, since lower state minimum wages, if they exist, apply to a tiny fraction of workers. In the analysis, we lag the minimum wage one year for all outcomes except employment, because in the Census data these outcomes are measured in the previous year; we do the same for the other policies, for the same reason. Finally, we use the log of the minimum wage. ${ }^{25}$

Figure 1 shows the minimum, average, and maximum minimum wage (measured on the left-hand axis); the minimum values measure the federal minimum wage. The gray boxes indicate the number of states with a minimum wage above the federal level (measured on the right-hand axis). As the figure indicates, this latter number is trivial early in the sample, but the number of states with higher minimum wages rises sharply in the 2000s, to over 30 .

Information on the EITC comes from a database of historical parameters maintained by the Tax Policy Center. ${ }^{26}$ We use the percentage supplement in the federal EITC for a family with two children on the phase-in range (F2\%), which can be amplified by the state EITC,

economic self-sufficiency is most salient.

${ }^{23}$ The main information in the latter is in the appendix of the working paper, at http://www.nber.org/dataappendix/w16355/Appendix\%20A\%20State\%20Laws.pdf (viewed February 15, 2017).

${ }^{24}$ If there was a conflict between sources, we chose the information in Quester (1980), to maintain consistency when constructing the panel.

${ }^{25}$ We use real (2014\$) minimum wages, although with the log transformation and year effects, the deflator is irrelevant. Historically, there has been some debate in the research literature over whether to define the minimum wage relative to an average wage measure. In recent work, this approach has fallen out of favor, and the log of the minimum wage is used instead. The data on minimum wages can be accessed at http://www.socsci.uci.edu/ dneumark/datasets.html (viewed February 15, 2017).

${ }^{26}$ See http://www.taxpolicycenter.org/sites/default/files/legacy/taxfacts/content/PDF/historical_eitc_parameters.pdf (viewed October 11, 2016). 
usually specified as a percentage supplement to the federal EITC (S\%). Thus, our combined variable is $F 2 \% \cdot(1+S \%)$, where $F 2 \%$ and $S \%$ are measured on a scale from zero to one. ${ }^{27}$

Figure 2 shows the EITC variation, displayed in a similar way. There was no EITC in 1970, and no state variation until after 1990. By the end of the sample period there are 23 states with an EITC supplement, and the maximum supplements increase the phase-in rate by over 15 percentage points.

We include two measures of welfare generosity or stringency. From 1962-1996, the United States joint federal and state social assistance program was known as Aid to Families with Dependent Children (AFDC). The program was reformed by Congress in 1996 and rebranded as Temporary Assistance for Needy Families (TANF). Our first measure is the maximum payment for a family of three, usually held to be one adult and two dependent children. ${ }^{28}$ Second, for the post-welfare reform period, we include a dummy variable for whether tight time limits were imposed. There were no time limits until welfare reform in 1996, after which 10 states adopted limits of less than 60 months (in 2000, ranging from 21-48 months, but generally about two years), and most of the remaining states adopted time limits of 60 months. We use a time limit dummy variable that is equal to zero for all states before welfare reform, and, after welfare reform, switches to one for states that imposed tight time limits (less than 60 months), to capture states that more substantially tightened eligibility for welfare. $^{29,30}$

\footnotetext{
${ }^{27}$ State credits are fully refundable (as is the federal credit), except for Delaware, Maine, Rhode Island, and Virginia. This would suggest that our estimates slightly understate the effects of refundable credits.

${ }^{28}$ We are typically able to measure benefits this way, but in some cases, we can only determine the level of benefits for a family of three. We always use the former when possible.

${ }^{29}$ We also explored distinguishing between states that imposed tighter time limits and those that imposed limits of 60 months (versus none), although the results were not affected.

${ }^{30}$ To be sure, there are many possible measures of welfare reform one could use (Fang and Keane, 2004). However, including many measures would be problematic because of multicollinearity, perhaps especially in our framework. Time limits seem like a good choice to capture the effects of welfare reform. A small but consistent literature has shown that welfare time limits were a significant element of welfare reform distinguishing TANF from AFDC, (Moffitt, 2007) and that they were responsible for decreasing welfare caseloads (e.g., Grogger, 2009).
} 


\section{All information on TANF comes from the Urban Institute’s Welfare Rules Database. ${ }^{31}$}

For AFDC, various sources were utilized. ${ }^{32}$ Some states had benefit amounts that varied by

subarea. Only for Illinois, Louisiana, Vermont, and Virginia were the regional benefit levels

and geographies reported with enough consistency to reconstruct their longitudinal series, and

even then, we had to fill in missing years. ${ }^{33}$ For the remaining states with region-specific

benefit amounts, in most cases the publications reported the highest payment amount across

regions, and this is what we used. However, in a few cases the publications did not consistently

state which region or amount they were reporting, so we could be overstating or understating

the benefit amount in certain years.

Figures 3 and 4 display information on the two welfare measures we use. Figure 3

graphs nominal benefit levels. There is substantial variation across states. Figure 4 displays

information on time limits.

Measuring Disadvantage

For our main analyses, we measure disadvantage as the share of the population living in

poverty in the baseline year. However, we also show key results for three alternative measures

of disadvantage: the share of the population with a high school degree or less; the share of the

\footnotetext{
${ }^{31}$ See http://wrd.urban.org/wrd/Query/query.cfm (viewed February 16, 2017).

${ }^{32}$ U.S. Department of Health and Human Services publications (Characteristics of State Plans [various years]) provided program parameters for 1973-1976, 1978-1985, and 1988-1990. For 1994 and 1996, program parameters came from U. S. House of Representatives publications (Green Book [various years]). For 1969 and 1970, publicly available information was incomplete. U.S. Department of Health, Education, and Welfare (various years) publications on selected state maximum welfare payments were used where available. For program parameters for years with missing data, the annualized growth rate between the two observed years that bracketed the missing year or years was calculated, and the benefit amount for the missing year or years was assumed to equal the previous year's amount times one plus the annualized growth rate.

${ }^{33}$ For these states, in years where the publications indicated that there was regional variation in benefit amounts but did not report them, we used the following method to estimate the missing amounts. First, if for a year $t$ with missing data, years $t-1$ and $t+1$ are observed and are the same, then year $t$ is assumed to be the same as those years. If only one region's amount was reported, we assumed the yearly growth rate was the same across regions, and extrapolated to the missing year/region on that basis. For years where no region-specific amounts were reported or specified, we used documents from the next year forward and used implied growth rates between known years to infill the missing amounts.
} 
population that is black; and the share of families headed by single mothers. ${ }^{34}$ The results are generally robust.

Figure 5 provides information on the geographic distribution of tracted areas as of 1970, and of our disadvantage measure. The figure shows areas tracted in 1970, with differential shading for tracts in the four quartiles of the share disadvantaged - based on the share in poverty. The darkest shading is for the highest quartile of this share - i.e., the most disadvantaged tracts. As the figure shows, a small geographic area was tracted, but the tracted areas include most of the population. ${ }^{35}$

\section{Results}

\section{Descriptive Statistics}

Table 1 reports descriptive statistics. Recall that these are means across tracts, not individual units. The top panel reports means (and standard deviations) for the outcomes we study. The earnings variable is average earnings per household, which we construct in the NCDB from data on earnings per household with workers, and the computed share of households with earnings. The earnings data are in nominal terms, which is why they rise sharply. The employment rate is simply the employment-to-population ratio at the tract level. The poverty rate measure is on a per person rather than per household or per family basis. Both track U.S. statistics closely, despite being tract-level observations. ${ }^{36}$

The share on public assistance is lower than the poverty rate (although it is a per

\footnotetext{
${ }^{34}$ This is the share of families and subfamilies. While tracts with large Hispanic populations are also of interest and likely, on average, to be disadvantaged, Hispanic ethnicity has not been measured consistently over the long time span we study.

35 The sum of the tracted population in 1970 was 148,456,474 (found from the NCDB) against a total U.S. 1970 population of 203,302,031 (U.S. Department of Commerce, 2002), or 73 percent of the U.S. population. Using the same sources, the figures are 80 percent and 99.99 percent of the population for 1980 and 1990, respectively.

${ }^{36}$ See, e.g., https://data.bls.gov/timeseries/LNS12300000 (viewed February 16, 2017) and http://www.census.gov/data/tables/time-series/demo/income-poverty/historical-poverty-people.html (viewed February 16, 2017).
} 
household measure, and the poverty rate is lower at the family or household than at the individual level). It drops sharply in the final years of the sample (the 2006-2010 period covered by the ACS) because SSI is excluded in the NCDB data. This change should not influence our results materially, since the definitional change should be captured in the year effects that are included in the model; ${ }^{37}$ moreover, we find that results are very similar for poverty and for public assistance - and the change in the data affects only the latter.

The second panel reports descriptive statistics for our four outcome measures for the disadvantaged tracts. As we would expect, earnings and employment are lower, and poverty and the share on public assistance are higher. The bottom panel reports the disadvantage measure for 1970 . We report the mean as well as the $75^{\text {th }}$ percentile of this measure; the latter is the cutoff for defining $D I S^{b}$.

\section{Baseline Regression Results}

We report baseline results for earnings, employment, poverty, and public assistance in Table 2. The table reports estimates of equation (2), reporting only the estimates of the coefficients $\beta$ and $\beta^{\mathrm{L}}$, on the variables $D I S^{b}{ }_{c} \cdot P_{c s t}$ and $D I S^{b}{ }_{c} \cdot P_{c s, t-10}$, respectively.

The estimates for average household earnings are in column (1). There is a positive and statistically significant contemporaneous effect of minimum wages on earnings, but the 10-year lag effect is negative and not statistically significant. Because earnings and the minimum wage are measured in logs (as are the EITC and welfare benefit variables), the estimated coefficients can be interpreted as the elasticities with respect to the minimum wage in the mostdisadvantaged (high-poverty) tracts, relative to other tracts. This way of specifying the model allows comparisons with minimum wage-earnings elasticities reported in other studies -

\footnotetext{
37 The table does not show a decline from 1990 to 2000. While AFDC/TANF rolls declined over this period, participation in SSI grew by an amount that offsets a large share of this decline (see, e.g., Figure IND 4, https://aspe.hhs.gov/report/welfare-indicators-and-risk-factors-fourteenth-report-congress, viewed November 29, 2017).
} 
although typically these other estimates are for low-skilled individuals and focus only on shortterm, contemporaneous effects. Short-term earnings effects could be negative, if there are adverse impacts on employment or hours. However, contemporaneous wage elasticities in the 0.1 to 0.2 range are not uncommon (e.g., Allegretto et al., 2011). ${ }^{38}$ The 0.15 estimate is in column (1) is in the middle of this range.

There is also statistically significant evidence of a positive short-run effect of the EITC on earnings, but no evidence of a longer-run effect. As discussed below, there is evidence of a positive longer-run effect of the EITC on employment. The absence of an earnings effect may reflect the fact that the EITC increases labor supply, which can depress market wages (Leigh, 2000). Finally, there is no evidence of statistically significant longer-run (or contemporaneous) effects of either welfare benefit levels or time limits on average household earnings.

Results for the employment rate are reported in column (2). There is evidence of a positive effect of minimum wages in the short run, with an elasticity of 0.24 . This result contrasts with a good deal of evidence in the broader literature on the employment effects of minimum wages. But the estimates here are for different groups - residents of tracts that were disadvantaged many decades back - as opposed to the low-skilled and usually very young workers considered in most of the minimum wage literature. The longer-run estimated employment effect is negative, but not significant (with an elasticity of -0.09).

We find a positive longer-run effect of the EITC on employment, with an elasticity of 0.025. We find no statistical evidence of a contemporaneous effect, and the point estimate is negative, which differs from the EITC literature focused on low-skilled, often single mothers. Again, this difference may reflect the fact that results for disadvantaged places can differ from what has been found using individual- or household-level data on the most affected groups. We

${ }^{38}$ There are exceptions. In a recent study of the Seattle minimum wage, Jardim et al. (2017) find negative effects on earnings. 
do find, however, that the estimated employment effect is larger for women than for men, which is what the prior literature - focusing on employment of less-skilled women - would lead us to expect (Appendix Table A1). ${ }^{39}$

For the welfare variables, we find no statistically significant evidence of longer-run effects on employment. This contrasts with the view that more generous welfare (higher benefits, or no or longer time limits) creates work disincentives. There is evidence of a significant negative short-run effect of tighter time limits, again contrary to the intended effect.

For two reasons, our most important results are for poverty and the share on public assistance. First, these are the direct "targets" of anti-poverty policies. And second, evidence on the longer-run effects of anti-poverty policies on poverty and receipt of public assistance tells us more about the effects of these policies on economic self-sufficiency. It is important to keep in mind that because both poverty and receipt of public assistance depend on the value of family income relative to thresholds, and because effects on family income depend on who is affected by the policies we consider, we should not necessarily expect a tight correspondence between effects on these outcomes and the prior earnings and employment results.

Because we should expect similar results for poverty and public assistance, we discuss these results together. The evidence on minimum wages in column (3) indicates that higher minimum wages reduce poverty in the longer-run, with an elasticity of -0.15 . There is also a longer-run reduction in the share of households on public assistance, coupled with evidence of a contemporaneous effect in the same direction. Past research on the short-run effects of the minimum wage on poverty have generally not found a significant effect (e.g., Sabia and Burkhauser, 2010), although the point estimates tend to be in the direction of reducing poverty,

${ }^{39}$ The estimated difference between men and women is not large, but most evidence of positive employment effects of the EITC for women focuses on unmarried women with children, whereas in the NCDB data we cannot measure employment rates for women distinguished by marital status and number of children. 
and Dube (2017) finds evidence of significant poverty reductions. Recent research has not found that higher minimum wages reduce participation in public assistance programs in the short-term (Sabia and Nguyen, 2017).

The estimates point to significant short-run and longer-run effects of the EITC in reducing both poverty and the receipt of public assistance. The longer-run elasticities are -0.04 and -0.10 , respectively. Note that the public assistance measure does not include the EITC, and EITC payments do not count in the poverty measure, so that these results indicate that the EITC reduces poverty and the receipt of other public assistance via behavioral changes - before taking account of the EITC (paralleling findings in Neumark and Wascher, 2011).

Finally, the estimates indicate that more generous welfare benefits increase poverty and public assistance receipt in the longer-run, with both elasticities around 0.17 . The result for receipt of public assistance may be somewhat mechanically linked to the level of benefits, given benefits formulas as well as take-up effects, and the same is potentially true of time limits. However, the fact that the results are so similar for poverty makes it more likely that we are detecting behavioral effects. We also find that tighter time limits appear to reduce poverty and public assistance. Note, however, that these effects of our two welfare measures are not reflected in positive effects on earnings or employment. This is not necessarily a contradiction; as noted earlier, because these outcomes are based on threshold definitions, there can be changes in the distribution but not the level of earnings, and these distributional changes can change the share poor or receiving public assistance. Moreover, time limits could reduce public assistance receipt without necessarily increasing earnings or employment. However, we are somewhat more cautious about the estimated longer-run effects of welfare benefits and time limits because of the absence of positive longer-run effects on earnings or employment.

Before moving on to discuss additional analyses, we briefly discuss three other sets of results that help establish the specification in Table 2 (and close variants thereof) as our 
preferred specification. First, in Appendix Table A2, we report results paralleling those in Table 2, but including the minimum wage, the EITC, and the welfare variables in separate specifications, rather than simultaneously. The minimum wage results are not at all robust to this alternative analysis, pointing to strong negative longer-run effects on employment, and strong positive longer-run effects on poverty and public assistance. The EITC results, and more so the welfare results, are robust. The minimum wage results are particularly interesting, because it is very much the norm in the minimum wage literature to exclude other policies from the regression models estimated (as it is, indeed, in many similar panel data analyses of the effects of other policies). In our context, at least, given that precision of the estimates does not decline much from including the three policies simultaneously (compare Table 2 and Appendix Table A2), it is preferable to include the three policies simultaneously.

Second, in Appendix Table A3 we report the results (noted earlier) that we obtain estimating a more saturated model including interactions between the indicator for disadvantaged tracts $\left(D I S^{b}\right)$ and year fixed effects. As the table shows, our estimated EITC effects are far less precise, especially for the longer-run effects, with standard errors that increase by a factor of 15 or more and lead to uninformative confidence intervals. Presumably reflecting this, the estimated EITC effects diverge quite widely from Table 2, with opposite signs for all of the estimated longer-run effects. The precision of the estimated effects of the other policies does not change much, but given that we saw the importance of controlling simultaneously for all three policies for pinning down the effects of minimum wages, it is not surprising that the estimated effects of minimum wages change dramatically in Appendix Table A3, pointing to large positive effects on poverty and public assistance. Because of the imprecision of the estimated EITC effects, we do not use this more saturated specification. As noted above, we already control for rich geographic heterogeneity in shocks to our outcomes.

Third, coding the generosity of welfare, especially post-welfare reform, is not as clear- 
cut as, for example, coding the minimum wage. It is difficult to capture the effects of welfare reform in a limited set of variables, as we noted earlier. One concern is that the effects of welfare benefits pre- and post-reform can be quite different, because it became much harder to get benefits in the latter period (e.g., Haveman et al., 2015). Our inclusion of the (tight) time limits variable should help on this score, as it flags states with potentially more stringent rules in the post-reform period. As another alternative, we modified the welfare benefits variable to also include an interaction with a post-1996 dummy variable, to allow the effects of benefits to change post-reform. (This variable was included in the same way as the main effect in the preceding specifications - contemporaneous and lagged, with both also interacted with $D I S^{b}$.)

The results, reported in Appendix Table A4, are quite robust, although the estimated longer-run effect of the EITC in reducing poverty - but not public assistance receipt - becomes smaller and significant. The key question, though, concerns the effects of the welfare variables. The interactions between the welfare benefit variables and the post-reform indicator are positive, but not significant. The estimated effects of benefits on poverty and public assistance in the pre-reform period remain positive and statistically significant, and the estimated effects of tighter time limits remain negative and statistically significant. Thus, nothing in this analysis indicates we need to distinguish the effects of welfare benefits pre- and post-reform.

\section{Additional Analyses}

We next turn to a number of additional analyses that assess the robustness or sensitivity of the results, including to important variations in the "treated" and "control" tracts that identify our effects. In our view, there are number of choices about precisely how to specify the model or sample. Our preferred choices are reflected in the baseline estimates we just discussed. But knowing how sensitive the results are to some of these choices naturally affects the confidence with which one should view our findings. 
First, we explore using alternative definitions of disadvantage for classifying tracts as disadvantaged at baseline: the share of the population with a high school degree or less; the share of the population that is black; and the share of families headed by single mothers. ${ }^{40}$ These results are reported in Table 3. Focusing on our key results - the longer-run effects on poverty and public assistance - the estimates are quite robust. We always find negative estimated effects of the minimum wage and the EITC on poverty, although the estimates are statistically significant only for the share black disadvantage measure. The evidence (including statistical significance) is more robust for the effects of the minimum wage and the EITC in reducing receipt of public assistance - especially for the EITC. The estimated effects of welfare benefits and time limits in reducing poverty and public assistance are the most robust; the magnitudes are similar across the three alternative measures of disadvantage, and most of the estimated effects are statistically significant. ${ }^{41}$

The second issue we consider is whether our results are driven by migration that changes the composition of the population in tract. We assess this by adding controls for migration capturing the proportion that moved into the tract from the same county, or from anywhere else. The estimates, reported in Table 4, are very robust to this change, indicating that compositional changes are not influential.

Next, we vary the comparison or control tracts used to identify the longer-run effects of anti-poverty policies on the most-disadvantaged tracts. First, we drop observations in the third quartile of the observations used to define DIS ${ }^{b}$. In this case, the "control” or "untreated" tracts are more sharply delineated from the tracts in the top quartile of disadvantage because we omit

\footnotetext{
40 The correlations of the indicators for the most-disadvantaged quartiles are as follows: share poor and share black: 0.44; share poor and share single mothers: 0.38 ; and share poor and share low-education: 0.25 . The corresponding correlations for the actual shares, rather than the dummy variables for the top quartile of disadvantage, are 0.55 , 0.62 , and 0.26 .

${ }^{41}$ We also find robust evidence of positive longer-run employment effects of the EITC, although also of modest reductions in average earnings - again presumably reflecting downward pressure on wages for some groups whose employment does not increase (and whose employment or hours may decrease).
} 
observations for which the share poor at the tract level is between the median and the $75^{\text {th }}$ percentile. Given that the policies we study would also be expected to affect low-wage earners or low-income families in other tracts, the inclusion of tracts in the third quartile of the distribution of disadvantage could bias our findings towards zero. We did not expect large changes, given that the anti-poverty policies we study target disadvantaged people and families, and there is considerable residential segregation by income across tracts (e.g., Watson, 2009). The results reported in Table 5 bear this out. Consistent with our conjecture, nearly every estimate in Table 5 is larger in absolute value than the corresponding baseline estimate in Table 2; and this is true for every statistically significant estimate in Table 2 (and Table 5). On the other hand, the estimates are not very different between Tables 2 and 5 . The similarity of the estimates suggests that the effects we estimate are strongly concentrated in the tracts in the top quartile of disadvantage, which is consistent with our research design.

The absence of much impact in the third quartile of disadvantage suggests that we might find quite similar results if we estimate our model only for the top two quartiles of disadvantage, estimating the longer-run effects of policy from changes in the most-disadvantaged tracts relative to tracts in the third quartile. The estimates in Table 6 show that this is indeed the case. Note, for example, that all of the longer-run effects of the minimum wage, the EITC, and our two welfare variables remain statistically significant, while the point estimates for the EITC and the welfare variables are generally smaller in absolute value. ${ }^{42}$

We view the evidence in Table 6 as significantly bolstering a causal interpretation of our findings. We think it is much less likely that there are different shocks hitting tracts in the top (fourth) and third quartiles of the distribution of disadvantage, whereas this is more plausible, a

\footnotetext{
${ }^{42}$ If the minimum wage effects are causal, one reason they may not weaken is that while minimum wage workers are distributed throughout the family income distribution, the effect of the minimum wage in reducing poverty (or public assistance) is concentrated in the poorest tracts.
} 
priori, for tracts in the top quartile versus those in the first and second quartiles. Hence, the similarity of results indicates that the rich controls in our model are adequately capturing variation attributable to other shocks that is potentially correlated with our policy variables.

We next present a robustness analysis in which we move up the baseline year in which we measure disadvantage by one decade - to 1980 - and estimate the models for 1990-2010 instead of 1980-2010. If the composition of tracts changed much from 1970 to 1980 , then a good part of our identification of effects for “disadvantaged” tracts may not reflect tracts that are as likely to be disadvantaged in later years, given that we use data over four decades for our main analysis. There is considerable persistence in our measure of disadvantage. However, the classification of tracts as disadvantaged in 1980 is more persistent than the classification in 1970. The shares of the tracts in the top quartile of the poverty distribution in 1970 that are in the top quartile one, two, and three decades later are 67.6 percent (1980), 59.2 percent (1990), and 58.8 percent (2000). The corresponding shares based on the 1980 data are 71.9 percent (1990), 71.8 percent (2000) and 61.7 percent (2010).

The results are reported in Table 7. The results for the EITC, and for welfare time limits, are very robust to this change. We still find statistically significant evidence that the longer-run effect of the EITC is to reduce poverty and public assistance (and to increase employment). And we find similar evidence for welfare time limits. In contrast, however, the results for minimum wages flip sign and become insignificant, as do the results for welfare benefits. Especially insofar as policymakers should be more interested in results based on more current data, this evidence suggests that we should not draw strong conclusions about the beneficial longer-run effects of either minimum wages or more stringent welfare benefits.

Two of the prior analyses accounted for changes in the composition of tracts due to migration (Table 5), or due to the passage of time (Table 7). Our next analysis explores a hybrid of these two issues. Rather than fixing the classification of disadvantaged tracts in a 
single baseline period (1970 in most tables, but as 1980 in Table 7), we allow the classification of tracts to evolve over time. (That is, we modify equation (2), changing the dummy variable for disadvantaged tracts from $D I S^{b}{ }_{c}$ to $D I S_{c, t-10)}{ }^{43}$ This specification allows the composition of tracts to change over time, which implies that we are more certain that we are estimating 10year lags of policy effects for tracts that were disadvantaged 10 years prior. At this same time, the composition changes could reflect long-term effects of policy, which is why we prefer the specification using a fixed baseline.

The results are reported in Table 8. The results are generally quite similar for the EITC and welfare, with two exceptions. First, the estimated longer-run effects of welfare benefits are larger; and second, the evidence that the EITC reduces poverty in the longer-run is weaker, although the evidence that it reduces public assistance does not change. More substantial is the change in results for the minimum wage. The evidence in Table 8 indicates longer-run effects that increase poverty and public assistance, with the effect on poverty statistically significant. Coupled with the evidence in Table 7, this is another indication that we cannot draw robust conclusions that higher minimum wages reduce poverty or public assistance in the longer run.

Our final analysis addresses additional evidence - in addition to the analysis using different quartiles of disadvantage for comparisons - on a causal interpretation of the findings. We add 10-year leads of our policy variables to our models, to see whether policy changes were correlated with prior changes in outcomes, which could lead to biased estimates of policy effects. For the leads corresponding to the most recent data in our sample, we use 2016 (for welfare) or 2017 values (for the EITC and minimum wage) - depending on data availability which nearly correspond to 10 years after the midrange of the 2006-2010 period.

The results, reported in Table 9, indicate that there are some significant partial

\footnotetext{
${ }^{43}$ The second and third terms in equation (2) become $\left.D I S_{c, t-10} \cdot P_{c s t}\right\} \cdot \beta+\left\{D I S_{c, t-10} \cdot P_{c s, t-10}\right\} \cdot \beta^{\mathrm{L}}$.
} 
correlations between our outcome variables and future policy changes. For the EITC, there are positive partial correlations for poverty and the share on public assistance. If both EITC generosity and poverty/public assistance are quite persistent over time, then this leading relationship creates a bias against finding beneficial effects of the EITC. This is what we find, as controlling for the leads generates stronger beneficial longer-run effects of the EITC on these outcomes - thus strengthening our conclusions for the EITC. In contrast, this analysis somewhat weakens the evidence that more generous welfare benefits increase poverty and public assistance, and that tighter time limits reduce them. Still, these effects of welfare policy on poverty remain statistically significant (only at the 10-percent level for time limits). ${ }^{44,45}$ Finally, although the leading effects of minimum wages are not statistically significant, including these leading effects eliminates the evidence of beneficial longer-run effects of minimum wages in reducing poverty and public assistance receipt.

\section{Conclusions}

Our goal in this paper is to estimate the longer-run effects of anti-poverty policies on key socioeconomic outcomes in disadvantaged areas. We study three policies - minimum wages, the Earned Income Tax Credit, and welfare (and welfare reform) - and estimate how these policies influence earnings and employment, and most important, poverty, and public assistance, in the most disadvantaged areas. The kinds of longer-run effects we estimate differ substantially from almost all research on the effects of these policies, although there are a few

\footnotetext{
${ }^{44}$ The pattern of bias for time limits is the same as for the EITC. In column (3), there is an estimated negative lead for tighter welfare time limits (significant at the 10-percent level). Assuming the same type of persistence, this implies a bias towards finding that tighter time limits reduce poverty, consistent with the smaller effect of the longer-run effect of tighter time limits once we include the leading effect (in the last row of column (3)). However, the leading effect for welfare benefits is negative, which - assuming the same persistence - should imply a bias against finding that more generous welfare benefits increase poverty and public assistance receipt. But including the leading effects has the opposite effect. This may be related to differences in the persistence of welfare benefits, especially coupled with the post-welfare reform issues discussed earlier.

${ }^{45}$ One might wonder whether the evidence of leading effects we find is driven in part by defining disadvantage in terms of the poverty rate, which is related to poverty and public assistance outcomes (although our outcomes are measured in later decades). However, the estimated leading effects and the implications for the estimates were similar using the other measures of disadvantage from Table 3 (results available upon request).
} 
exceptions that focus on longer-run effects of a single one of these policies. Our consideration of multiple policies simultaneously is unique, as is our relatively long-run focus and our emphasis on disadvantaged areas.

We identify tracts that are initially disadvantaged in terms of a high share of residents who are poor. We then estimate the longer-run effects of these alternative policies on key economic indicators of economic self-sufficiency - in particular, poverty and the receipt of public assistance, but also employment and earnings.

In our view, a few key general results emerge. First, although we find, in our baseline specifications, that higher minimum wages lead to longer-run declines in poverty and the share of families on public assistance, this evidence is not robust. In other analyses we run, including limiting the analysis to more recent data or using a more recent definition of disadvantaged tracts, the evidence points in the opposite direction.

Second, we find some evidence that higher welfare benefits had longer-run adverse effects in increasing poverty and public assistance, whereas tighter welfare time limits reduce poverty and public assistance in the longer-run. The evidence on welfare benefits is not robust to the sample period. The evidence on time limits is not reflected in longer-run effects on employment and earnings, although it does not necessarily have to be given that changes in the distribution of earnings can generate changes in the share poor, and time limits can directly impact eligibility for public assistance.

Finally, we find that the longer-run effects of the EITC are to increase employment and to reduce poverty and public assistance. The EITC results do hinge on relying on national as well as state variation in EITC policy.

In our view, our most robust findings are that the EITC has beneficial longer-run impacts in terms of reducing poverty and public assistance, whereas there is essentially no evidence that more generous welfare delivers such longer-run benefits, and some evidence that 
more generous welfare has adverse longer-run effects on poverty and reliance on public assistance - especially with regard to time limits.

The comparison across anti-poverty policies is perhaps the most important evidence we provide. In our view, we have captured the main anti-poverty policies that target working-age adults and that can affect both their work incentives and their income from work. Given the strong, short-term pro-work incentives of the EITC established in other research, the evidence we find of beneficial longer-run effects of the EITC might seem like a natural conclusion. But it is by no means a foregone conclusion, as there is virtually no evidence on longer-run effects, nor evidence that simultaneously looks as these key anti-poverty policies. And we caution that more work is needed to pin down EITC effects, given that our results depend on using national policy variation, while at least one paper has found beneficial (short-run) effects of the EITC using only the state-level variation (e.g., Neumark and Wascher, 2011).

Our evidence on how anti-poverty policies change economic outcomes in disadvantaged neighborhoods could connect in important ways to the intergenerational mobility literature, which emphasizes the importance of place in longer-run economic outcomes. Moreover, it may be possible to draw some specific policy links. For example, one key finding in this research is that neighborhoods with larger fractions of single parents are associated with poorer future outcomes for children (Chetty et al., 2014). This suggests that beneficial longer-run effects of the EITC in reducing poverty could also lead to positive intergenerational effects.

Finally, we have focused on the longer-run effects of three key policies chosen because they are most likely to affect work incentives. In principle, of course, a whole set of policies, going back to early childhood interventions, could have longer-run effects on labor market outcomes of individuals, families, and neighborhoods. ${ }^{46}$ Most work, even on short-term policy

\footnotetext{
${ }^{46}$ See the extensive inventory of such policies, and research summaries, in Neumark (2016).
} 
effects on labor market outcomes, has focused on policies in isolation, and the same is true of the much more miniscule literature on longer-run policy effects. We readily acknowledge, however, that there is potentially a great deal more to be learned from simultaneously considering the effects of more policies, including their interactions, although the empirical challenges are likely to be severe. Moreover, the fact that some of our findings depend on the sources of policy variation used to identify the effects we estimate highlights that there are further challenges in estimating longer-run policy effects. 


\section{$\underline{\text { References }}$}

Acemoglu, Daron, and Jörn-Steffen Pischke. 2003. "Minimum Wages and On-the-Job Training.” Research in Labor Economics 22: 159-202.

Agell, Jonas, and Kjell Erik Lommerud. 1997. "Minimum Wages and the Incentives for Skill Formation.” Journal of Public Economics 64(1): 25-40.

Allegretto, Sylvia, Arindrajit Dube, and Michael Reich. 2011. "Do Minimum Wages Really Reduce Teen Employment? Accounting for Heterogeneity and Selectivity in State Panel Data.” Industrial Relations 50(2): 205-40.

Almond, Douglas, Hilary Hoynes, and Diane W. Schanzenbach. 2011. "Inside the War on Poverty: The Impact of Food Stamps on Birth Outcomes.” Review of Economics and Statistics 93(2): 387-403.

Autor, David H., David Dorn, and Gordon H. Hanson. 2013. "The China Syndrome: Local Labor Market Effects of Import Competition in the United States.” American Economic Review 103(6): 2121-68.

Bartik, Timothy J. 1991. Who Benefits from State and Local Economic Development Policies? Kalamazoo, MI: W.E. Upjohn Institute for Employment Research.

Bastian, Jacob, and Katherine Michelmore. “The Long-Term Impact of the Earned Income Tax Credit on Children's Education and Employment Outcomes.” Forthcoming in Journal of Labor Economics.

Bishaw, Alemayahu. 2014. “Changes in Areas with Concentrated Poverty: 2000 to 2010.” American Community Survey Reports. U.S. Census Bureau, June.

Bitler, Marianne, Jonah Gelbach, and Hilary Hoynes. 2006. "What Mean Impacts Miss: Distributional Effects of Welfare Reform Experiments.” American Economic Review 86(4): 988-1012.

Bogue, Donald. 2000a. “Census Tract Data, 1940: Elizabeth Mullen Bogue File.” ICPSR02930v1. Ann Arbor, MI: Inter-university Consortium for Political and Social Research [distributor], available at http://doi.org/10.3886/ICPSR02930.v1 (viewed February 15, 2015).

Bogue, Donald. 2000b. “Census Tract Data, 1950: Elizabeth Mullen Bogue File. ICPSR02931-v1. Ann Arbor, MI: Inter-university Consortium for Political and Social Research [distributor], available at http://doi.org/10.3886/ICPSR02931.v1 (viewed February 15, 2015).

Bogue, Donald. 2000c. “Census Tract Data, 1960: Elizabeth Mullen Bogue File. ICPSR02932-v1. Ann Arbor, MI: Inter-university Consortium for Political and Social Research [distributor], available at http://doi.org/10.3886/ICPSR02932.v1 (viewed February 15, 2015).

Card, David, and Dean R. Hyslop. 2005. "Estimating the Effects of a Time-Limited Earnings Subsidy for Welfare-Leavers.” Econometrica 73(6): 1723-70.

Chetty, Raj, Nathaniel Hendren, Patrick Kline, and Emmanuel Saez. 2014. "Where Is the Land of Opportunity? The Geography of Intergenerational Mobility in the United States.” Quarterly Journal of Economics 129(4): 1553-622.

Clemens, Jeffrey, and Michael Wither. 2016. "The Minimum Wage and the Great Recession: Evidence of Effects on the Employment and Income Trajectories of Low-Skilled Workers.” Unpublished paper.

Dahl, Molly, Thomas DeLeire, and Jonathan Schwabish. 2009. “Stepping Stone or Dead End? The 
Effect of the EITC on Earnings Growth.” National Tax Journal 62(2): 329-46.

Dube, Arindrajit. 2017. “Minimum Wages and the Distribution of Family Incomes.” IZA Discussion Paper 10572.

Dube, Arindrajit, T. William Lester, and Michael Reich. 2010. "Minimum Wage Effects Across State Borders: Estimates Using Contiguous Counties.” Review of Economics and Statistics 92(4): 945-64.

Eissa, Nada, and Jeffrey B. Liebman. 1996. "Labor Supply Response to the Earned Income Tax Credit.” Quarterly Journal of Economics 111(2): 605-37.

Fang, Hanming, and Michael P. Keane. 2004. “Assessing the Impact of Welfare Reform on Single Mothers.” Brookings Papers on Economic Activity 1: 1-95.

Federal Reserve System and Brookings Institution. 2008. The Enduring Challenge of Concentrated Poverty in America: Case Studies from Communities Across the U.S., available at https://www.brookings.edu/wp-content/uploads/2016/06/1024_concentrated_poverty.pdf (viewed February 13, 2017).

Grogger, Jeffrey. 2009. "Welfare Reform, Returns to Experience, and Wages: Using Reservation Wages to Account for Sample Selection Bias.” Review of Economics and Statistics 91(3): 490-502.

Grogger, Jeffrey. 2003. "The Effects of Time Limits, the EITC, and Other Policy Changes on Welfare Use, Work, and Income among Female-Headed Households.” Review of Economics and Statistics 85(2): 394-408.

Haveman, Robert, Rebecca Blank, Robert Moffitt, Timothy Smeeding, and Geoffrey Wallace. 2015. "The War on Poverty: Measurement, Trends, and Policy.” Journal of Policy Analysis and Management 34(3): 593-638.

Hotz, V. Joseph, Guido W. Imbens, and Jacob A. Klerman. 2006. "Evaluating the Differential Effects of Alternative Welfare-to-Work Training Components: A Reanalysis of the California GAIN Program.” Journal of Labor Economics 24(3): 521-66.

Hoynes, Hilary, Doug Miller, and David Simon. 2015. "Income, the Earned Income Tax Credit, and Infant Health.” American Economic Journal: Economic Policy 79(1): 172-211.

Krieger, Nancy. 2006. “A Century of Census Tracts: Health \& the Body Politic (1906-2006).” Journal of Urban Health 83(3): 355-361.

Jardim, Ekaterina, Mark C. Long, Robert Plotnick, Emma van Inwegen, Jacob Vigdor, and Hilary Wething. 2017. "Minimum Wage Increases, Wages, and Low-Wage Employment: Evidence from Seattle.” NBER Working Paper No. 23532.

Ladd, Helen F. 1993. “Spatially Targeted Economic Development Strategies: Do They Work?” Cityscape 1(1): 193-218.

Leigh, Andrew. 2010. "Who Benefits from the Earned Income Tax Credit? Incidence Among Recipients, Coworkers, and Firms.” The B.E. Journal of Economic Analysis and Policy (Advances), 10(1): Article 45 (on-line).

Meyer, Bruce D. 2010. “The Effects of the Earned Income Tax Credit and Recent Reforms.” In J. R. Brown (Ed.) Tax Policy and the Economy, Volume 24. Chicago: University of Chicago Press, pp. 153-80.

Meyer, Bruce D., and Dan T. Rosenbaum. 2001. "Welfare, the Earned Income Tax Credit, and the Labor Supply of Single Mothers.” Quarterly Journal of Economics 116(3): 1063-114. 
Moffit, Robert. 2007. “Welfare Reform: The US Experience.” Working Paper 2008:13, Institute for Labour Market Policy Evaluation, available at https://www.econstor.eu/bitstream/10419/45781/1/573610746.pdf (viewed November 30, 2017).

Moffitt, Robert. 2015. "The U.S. Safety Net and Work Incentives: The Great Recession and Beyond.” Journal of Policy Analysis and Management 34(2): 458-66.

Murray, Charles. 1984. Losing Ground: American Social Policy, 1950-1980. New York: Basic Books.

Neumark, David. 2016. Inventory of Research on Economic Self-Sufficiency. Economic SelfSufficiency Policy Research Institute, UCI. Available at http://www.esspri.uci.edu/files/docs/2016/2016\%20ESSPRI\%20Preliminary\%20Research\%20 Inventory.pdf (viewed April 19, 2017).

Neumark, David, Brian Asquith, and Brittany Bass. In progress. "Understanding the Long-Run Effects of Anti-Poverty Policies on Disadvantaged Neighborhoods.”

Neumark, David, and Olena Nizalova. 2007. "Minimum Wage Effects in the Longer Run.” Journal of Human Resources 42(2): 435-52.

Neumark, David, J.M. Ian Salas, and J.M. Ian Salas. 2014. "Revisiting the Minimum WageEmployment Debate: Throwing Out the Baby with the Bathwater?” Industrial and Labor Relations Review 67(Supplement): 608-48.

Neumark, David, and Peter Shirley. 2017. “The Long-Run Effects of the Earned Income Tax Credit on Women's Earnings.” NBER Working Paper No. 24114.

Neumark, David, and Helen Simpson. 2015. “Place-Based Policies.” In Handbook of Regional and Urban Economics, Vol. 5, Gilles Duranton, Vernon Henderson, and William Strange, eds. (Amsterdam: Elsevier), pp. 1197-287.

Neumark, David, and William Wascher. 2011. "Does a Higher Minimum Wage Enhance the Effectiveness of the Earned Income Tax Credit?” Industrial and Labor Relations Review 64(4): 712-46.

Neumark, David, and William Wascher. 2007. “Minimum Wages and Employment.” Foundations and Trends in Microeconomics 3(1-2): 1-186.

Neumark, David, and Timothy Young. In progress. "The Longer-Run Effects of Enterprise Zones.”

Neumark, David, and Timothy Young. 2017. “Government Programs Can Improve Local Labor Markets, But Do They? A Re-Analysis of Ham, Swenson, Imrohoroğlu, and Song (2011).” IZA Discussion Paper No. 11168.

Quester, Aline O. 1980. “State Minimum Wage Laws, 1950-1980.” In Report of the Minimum Wage Study Commission, Vol 2. The Commission, June 1981, 23-152.

Rosenbaum, Dorothy. 2013. The Relationship Between SNAP and Work Among Low-Income Households. Center on Budget and Policy Priorities, Washington, DC.

Sabia, Joseph J., and Richard V. Burkhauser. 2010. “Minimum Wages and Poverty: Will a \$9.50 Federal Minimum Wage Really Help the Working Poor?” Southern Economic Journal 76(3): 592-623.

Sabia, Joseph J., and Thanh Tam Nguyen. 2017. “Do Minimum Wages Really Reduce Public Assistance Receipt?” Unpublished paper, San Diego State University. 
Sutch, Richard. 2010. “The Unexpected Long-Run Impact of the Minimum Wage: An Educational Cascade.” In P.W. Rhode, J.L. Rosenbloom, and D. Weiman (Eds.) Economic Evolution and Revolution in Historical Time. Stanford: Stanford University Press, pp. 387-418.

Tatian, Peter A., Chris Hayes, Simone Zhang. 2003. “Neighborhood Change Database, 1970-2010 Tract Data, Data Users’ Guide Long Form Release, Appendix L.” Washington, D.C., The Urban Institute, 2003, pp. 1-8.

Thompson, Jeffrey P. 2009. "Using Local Labor Market Data to Re-Examine the Employment Effects of the Minimum Wage.” Industrial and Labor Relations Review 62(3): 343-66.

U.S. Department of Commerce, Bureau of the Census. 1994. Geographic Areas Reference Manual. Washington, D.C.: U. S. Department of Commerce, Economics and Statistics Administration, Bureau of the Census.

U.S. Department of Commerce, Bureau of the Census. 2002. Measuring America: The Decennial Censuses from 1790 to 2000. Washington, D.C.: U. S. Department of Commerce, Economics and Statistics Administration, Bureau of the Census.

U.S. Department of Health and Human Services. Various years. Characteristics of State Plans for Aid to Families with Dependent Children. Washington, DC: U.S. Department of Health and Human Services, Administration for Children and Families, Office of Family Assistance.

U.S. Department of Health, Education, and Welfare. Various years. Aid to Families with Dependent Children: State Maximums and Other Limitations on Money Payments, And Federal Matching Provisions Under the Social Security Act. Washington, DC: U.S. Department of Health, Education, and Welfare, Social and Rehabilitation Service, Office of Information Sciences, National Center for Social Statistics.

Watson, Tara. 2009. "Inequality and the Measurement of Residential Segregation by Income in American Neighborhoods.” Review of Income and Wealth 55(3): 820-44.

Wilson, William J. 1990. The Truly Disadvantaged: The Inner City, the Underclass, and Public Policy. Chicago: University of Chicago Press. 
Figure 1: State Level Minimum Wage Variation (Nominal)

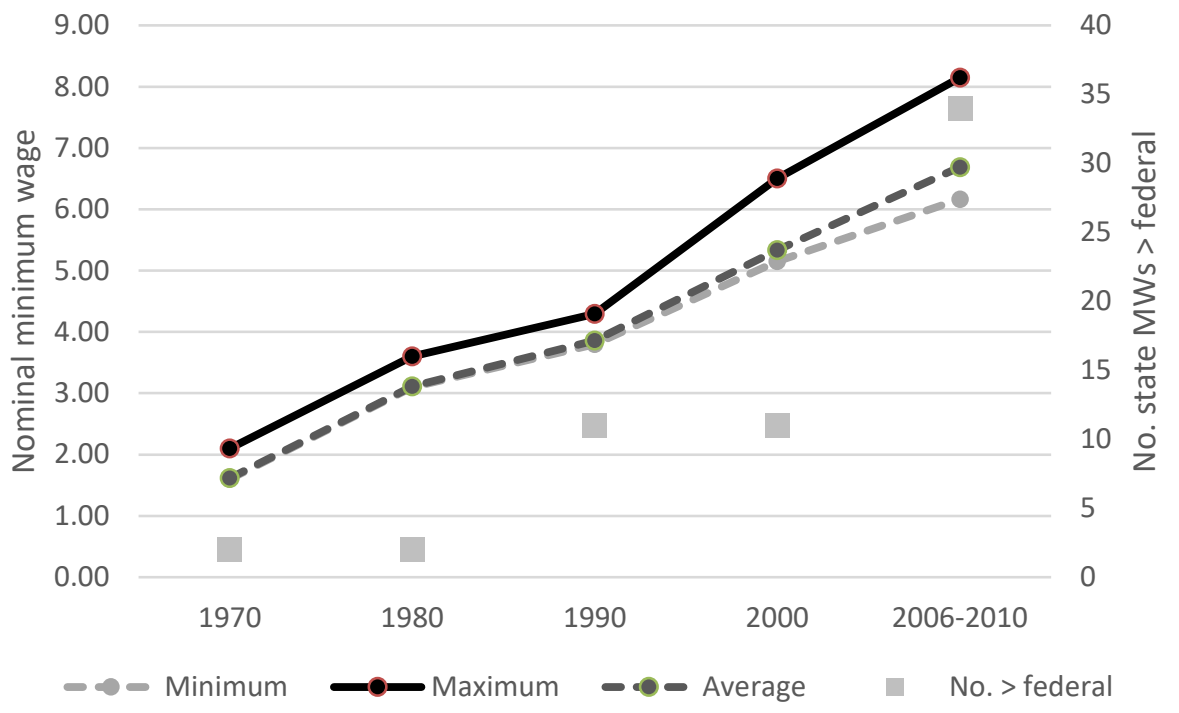

Figure 2: State Level EITC Variation (Phase-In Rate, 2 Children)

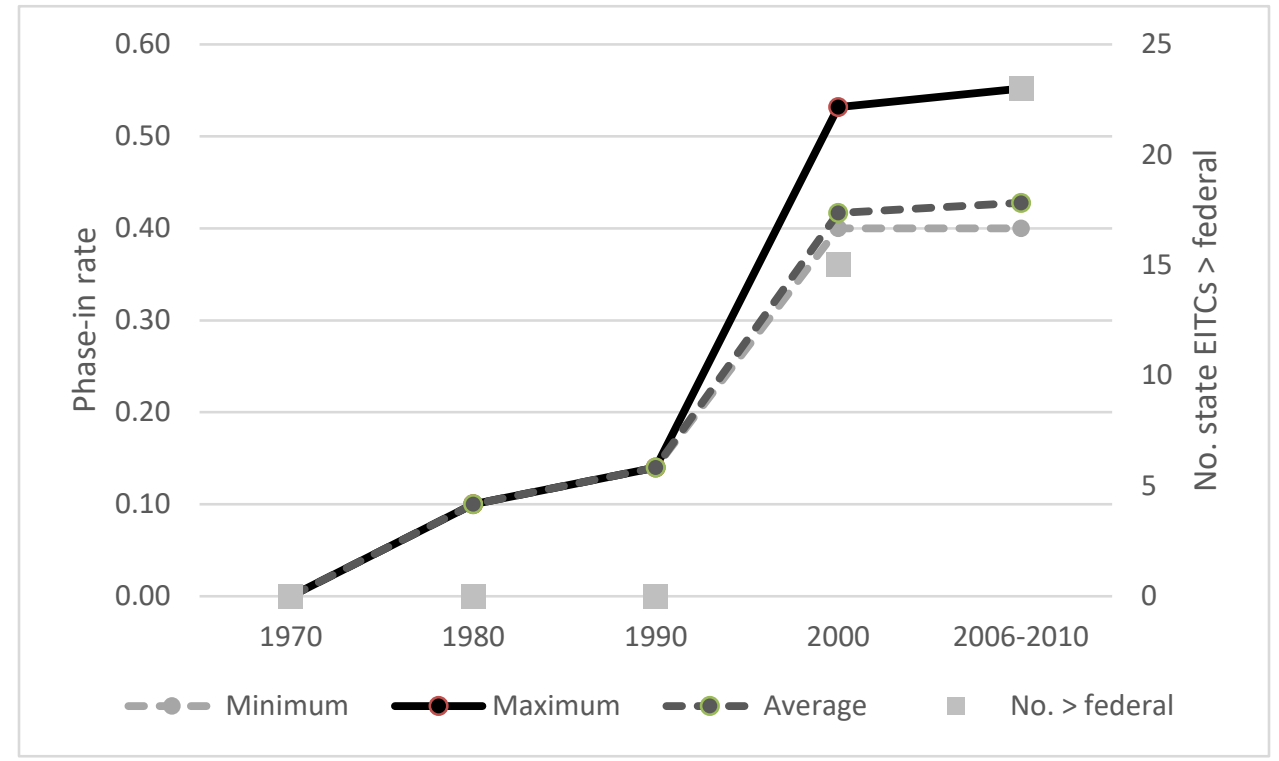


Figure 3: Welfare Benefits (Nominal) for Family of Three

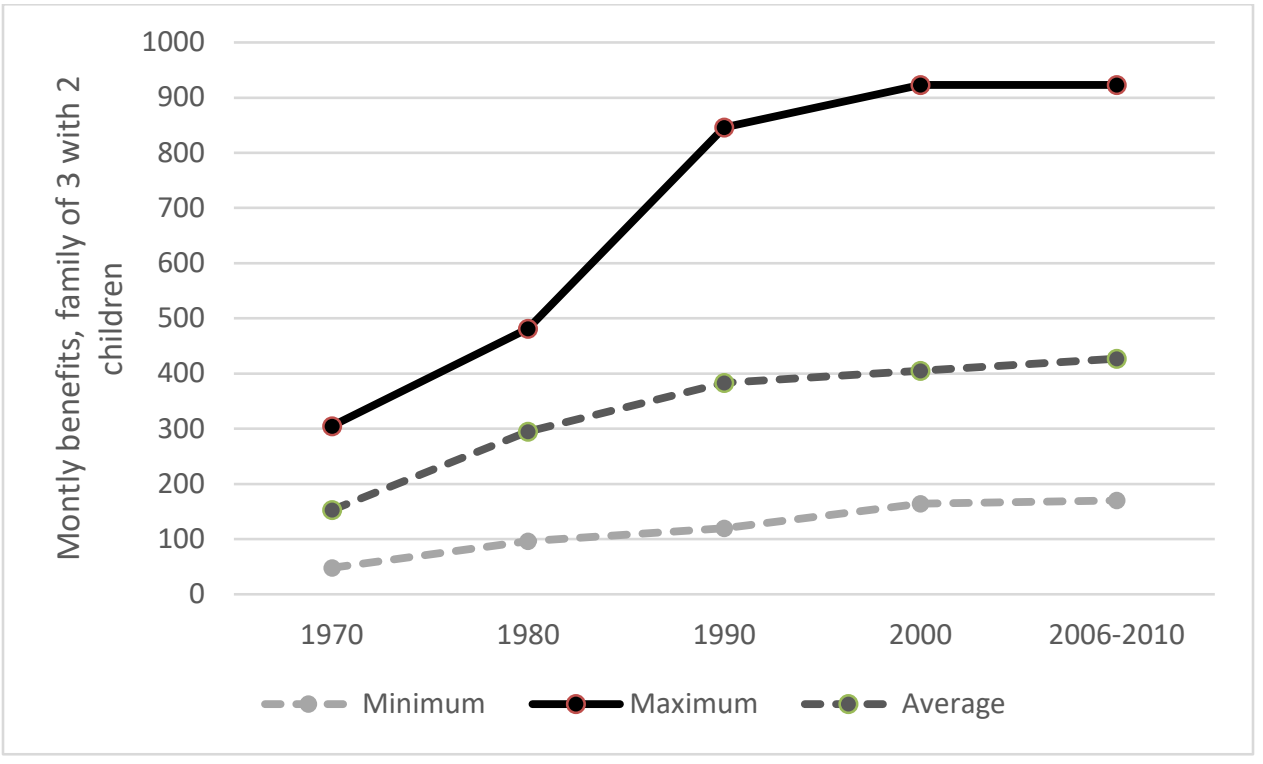

Figure 4: Welfare Time Limits

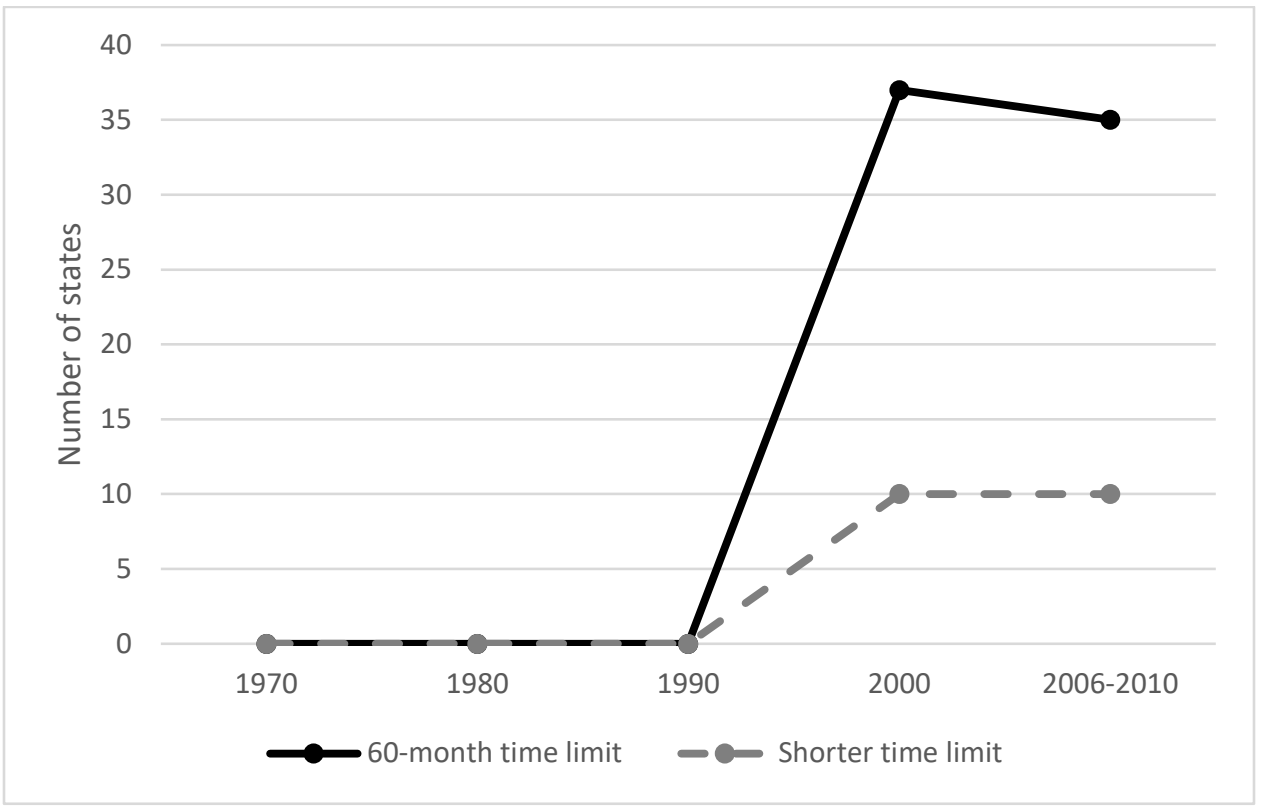


Figure 5: 1970 Disadvantage by Tract, Based on Share in Poverty, for Areas Tracted in 1970

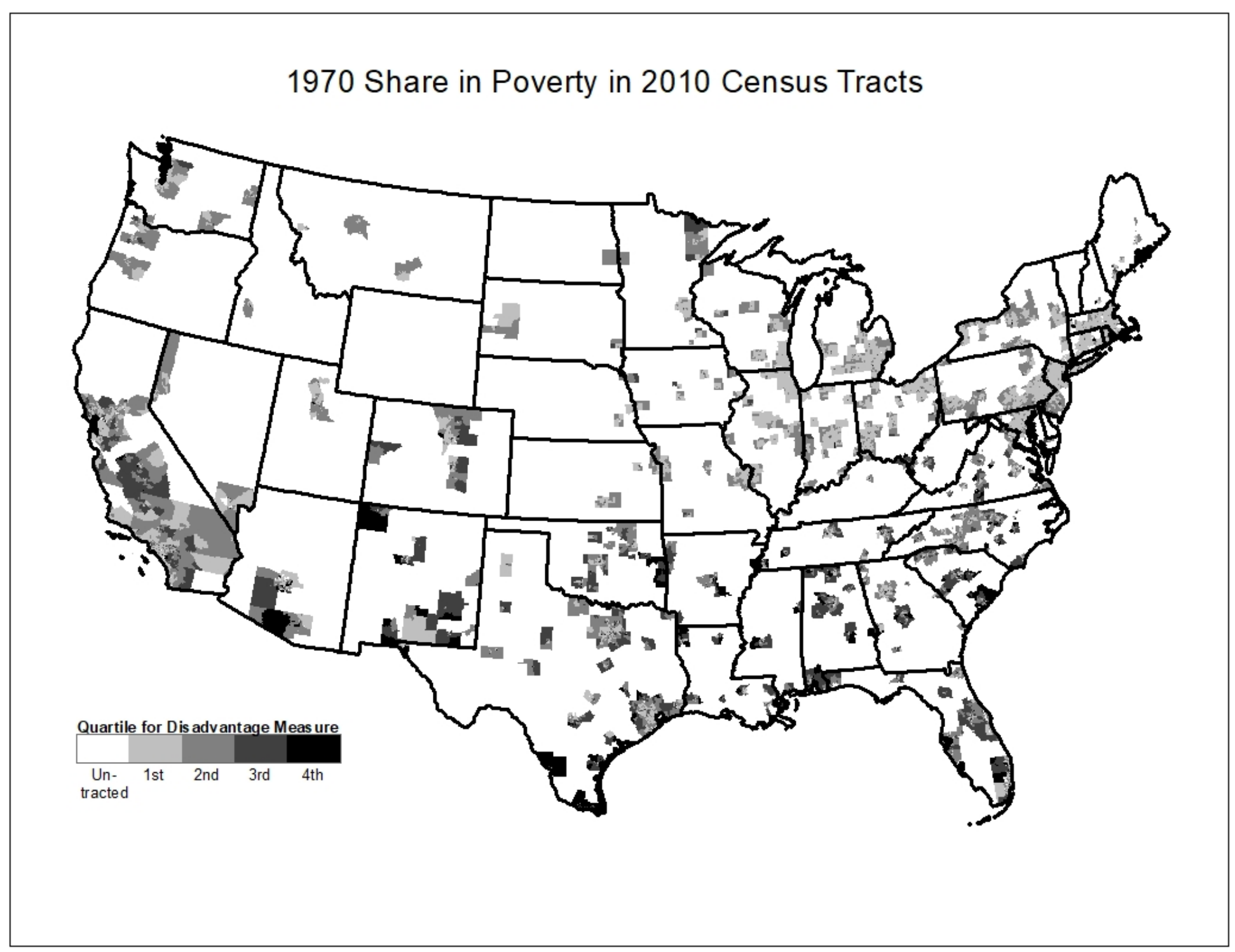


Table 1: Descriptive Statistics on Outcomes and Tract Characteristics

\begin{tabular}{|c|c|c|c|c|}
\hline & 1980 & 1990 & 2000 & $\begin{array}{c}2006-2010 \\
\text { (average) }\end{array}$ \\
\hline & $(1)$ & $(2)$ & (3) & $(4)$ \\
\hline \multicolumn{5}{|l|}{ Outcomes } \\
\hline Average earnings per household (nominal) & $\begin{array}{l}18,596.5 \\
(7,510.8)\end{array}$ & $\begin{array}{c}34,497.8 \\
(16,825.4)\end{array}$ & $\begin{array}{c}48,765.7 \\
(24,482.2)\end{array}$ & $\begin{array}{r}60,079.7 \\
(32,631.8)\end{array}$ \\
\hline Employment rate, male and female civilians aged $16^{+}$ & $\begin{array}{c}59.6 \\
(10.6)\end{array}$ & $\begin{array}{c}62.4 \\
(11.4)\end{array}$ & $\begin{array}{c}60.5 \\
(11.2)\end{array}$ & $\begin{array}{c}61.8 \\
(11.2)\end{array}$ \\
\hline Employment rate, female civilians aged $16+$ & $\begin{array}{c}48.6 \\
(10.4)\end{array}$ & $\begin{array}{c}54.8 \\
(11.3)\end{array}$ & $\begin{array}{c}54.6 \\
(10.9)\end{array}$ & $\begin{array}{c}56.5 \\
(11.4)\end{array}$ \\
\hline Employment rate, male civilians aged $16+$ & $\begin{array}{c}71.8 \\
(12.2)\end{array}$ & $\begin{array}{c}70.8 \\
(12.5)\end{array}$ & $\begin{array}{c}67.1 \\
(12.7)\end{array}$ & $\begin{array}{c}67.8 \\
(13.5)\end{array}$ \\
\hline Share of population in poverty & $\begin{array}{c}11.1 \\
(10.5)\end{array}$ & $\begin{array}{c}12.4 \\
(12.4)\end{array}$ & $\begin{array}{c}12.7 \\
(11.7)\end{array}$ & $\begin{array}{c}14.6 \\
(13.1)\end{array}$ \\
\hline Share of households on public assistance & $\begin{array}{c}7.52 \\
(8.19)\end{array}$ & $\begin{array}{c}7.56 \\
(8.51)\end{array}$ & $\begin{array}{c}8.29 \\
(8.18)\end{array}$ & $\begin{array}{c}2.83 \\
(3.68)\end{array}$ \\
\hline \multicolumn{5}{|c|}{ Outcomes: most-disadvantaged tracts (share in poverty, 1970) } \\
\hline Average earnings per household (nominal) & $\begin{array}{l}12,830.6 \\
(5,361.9)\end{array}$ & $\begin{array}{c}23,889.8 \\
(12,007.5)\end{array}$ & $\begin{array}{c}35,589.5 \\
(18,342.4)\end{array}$ & $\begin{array}{c}44,809.2 \\
(26,095.8)\end{array}$ \\
\hline Employment rate, male and female civilians aged $16+$ & $\begin{array}{c}52.4 \\
(11.0)\end{array}$ & $\begin{array}{c}54.9 \\
(12.9)\end{array}$ & $\begin{array}{c}53.8 \\
(12.8)\end{array}$ & $\begin{array}{c}56.6 \\
(12.9)\end{array}$ \\
\hline Share of population in poverty & $\begin{array}{c}22.4 \\
(13.5)\end{array}$ & $\begin{array}{c}24.6 \\
(16.0)\end{array}$ & $\begin{array}{c}23.0 \\
(14.8)\end{array}$ & $\begin{array}{c}24.2 \\
(16.1)\end{array}$ \\
\hline Share of households on public assistance & $\begin{array}{c}14.8 \\
(11.8)\end{array}$ & $\begin{array}{c}14.7 \\
(12.2)\end{array}$ & $\begin{array}{c}14.5 \\
(11.1)\end{array}$ & $\begin{array}{c}4.49 \\
(5.22) \\
\end{array}$ \\
\hline \multicolumn{5}{|l|}{ Measures of disadvantage, 1970} \\
\hline & \multicolumn{2}{|c|}{ Mean (SD) } & \multicolumn{2}{|c|}{$75^{\text {th }}$ percentile } \\
\hline Initial share poverty & \multicolumn{2}{|c|}{$\begin{array}{c}10.9 \\
(9.72)\end{array}$} & \multicolumn{2}{|c|}{13.7} \\
\hline
\end{tabular}

Notes: Table reports means for tract-level measures, not individual-level measures. Standard deviations are shown in parentheses. Samples vary slightly across the different outcomes studied; sample sizes are reported in the following tables. The estimates for the shares and percentiles of the disadvantage variables are for the samples used for the earnings regressions. The public assistance definition excludes SSI for 2006-2010. 
Table 2: Effects of Anti-Poverty Policies on Average Earnings per Household, Employment Rate, Share in Poverty, and Share on Public Assistance in Areas with High Poverty Rate at Baseline (1970), 1980-2010

\begin{tabular}{|c|c|c|c|c|}
\hline & Earnings & Employment & Poverty & $\begin{array}{c}\text { Public } \\
\text { assistance }\end{array}$ \\
\hline & $(1)$ & $(2)$ & (3) & (4) \\
\hline \multirow[t]{2}{*}{ Log minimum wage } & $0.1474^{*}$ & $0.2359 * * *$ & -0.0608 & $-0.3102 *$ \\
\hline & $(0.0865)$ & $(0.0522)$ & $(0.1272)$ & $(0.1750)$ \\
\hline \multirow[t]{2}{*}{ 10-year lag of log minimum wage } & -0.0945 & -0.0925 & $-0.1464 *$ & $-0.3437 * *$ \\
\hline & $(0.0656)$ & $(0.0721)$ & $(0.0824)$ & $(0.1680)$ \\
\hline \multirow[t]{2}{*}{ Log EITC phase-in rate } & $0.0537 * *$ & -0.0168 & $-0.2095 * * *$ & $-0.1869 * * *$ \\
\hline & $(0.0256)$ & (0.0193) & $(0.0303)$ & $(0.0527)$ \\
\hline \multirow[t]{2}{*}{ 10-year lag of log EITC phase-in rate } & 0.0087 & $0.0248 * * *$ & $-0.0415^{* * *}$ & $-0.1015^{* * *}$ \\
\hline & (0.0109) & $(0.0063)$ & $(0.0146)$ & $(0.0219)$ \\
\hline \multirow[t]{2}{*}{ Log maximum welfare benefit } & 0.0389 & -0.0007 & 0.0308 & 0.0312 \\
\hline & $(0.0361)$ & $(0.0191)$ & $(0.0719)$ & $(0.0822)$ \\
\hline \multirow[t]{2}{*}{ 10-year lag of log maximum welfare benefit } & -0.0158 & 0.0000 & $0.1661 * * *$ & $0.1671^{* * *}$ \\
\hline & $(0.0185)$ & $(0.0113)$ & (0.0331) & $(0.0404)$ \\
\hline \multirow{2}{*}{ Welfare time limits (<60 months) } & -0.0068 & $-0.0282 * *$ & -0.0220 & 0.0088 \\
\hline & $(0.0230)$ & $(0.0110)$ & $(0.0246)$ & $(0.0301)$ \\
\hline \multirow[t]{2}{*}{ 10-year lag of welfare time limits ( $<60$ months) } & -0.0106 & -0.0158 & $-0.0790 * * *$ & $-0.1027 * *$ \\
\hline & $(0.0268)$ & $(0.0134)$ & $(\mathbf{0 . 0 2 6 3 )}$ & $(0.0491)$ \\
\hline Adjusted $\mathrm{R}^{2}$ & 0.69 & 0.74 & 0.79 & 0.77 \\
\hline $\mathrm{N}$ & 206,675 & 206,836 & 206,710 & 206,675 \\
\hline Tract fixed effects & Yes & Yes & Yes & Yes \\
\hline County x year interactions & Yes & Yes & Yes & Yes \\
\hline
\end{tabular}

Notes: The specification corresponds to equation (2) in the text; only the coefficients of $D I S^{b} \cdot P_{c s t}$ and $D I S^{b} \cdot{ }_{c} \cdot P_{c s, t-10}$ are reported. Earnings are defined as average earned income per household. All outcomes, and the minimum wage, EITC, and welfare benefits variables, are in logs. (The EITC phase-in rate is scaled from zero to 100, with one replacing zero, prior to taking logs.) Thus, the estimates of the minimum wage, EITC, and welfare benefits coefficients can be interpreted as elasticities for the disadvantaged tracts (i.e., those in the top quartile of disadvantage), relative to other tracts. The welfare time limits variable is a dummy variable, so its estimated effect approximates the percentage change in the outcome in disadvantaged tracts when welfare time limits are shorter. ${ }^{* * *},{ }^{* *}$, or ${ }^{*}$ indicates statistically significantly different from zero at the 1-, 5-, or 10-percent level. Standard errors are clustered by state. 
Table 3: Effects of Anti-Poverty Policies on Average Earnings per Household, the Employment Rate, the Share in Poverty, and the Share on Public Assistance, in Areas with Low Education, High Share Black, or High Share of Single Mothers at Baseline (1970), 1980-2010

\begin{tabular}{|c|c|c|c|c|c|c|c|c|c|c|c|c|}
\hline & \multicolumn{3}{|c|}{ Average earnings per household } & \multicolumn{3}{|c|}{ Employment rate } & \multicolumn{3}{|c|}{ Share in poverty } & \multicolumn{3}{|c|}{ Share on public assistance } \\
\hline & $\begin{array}{l}\text { Share } \\
\leq \text { HSG }\end{array}$ & $\begin{array}{l}\text { Share } \\
\text { black }\end{array}$ & $\begin{array}{c}\text { Share } \\
\text { SM }\end{array}$ & $\begin{array}{l}\text { Share } \\
\leq \text { HSG }\end{array}$ & $\begin{array}{l}\text { Share } \\
\text { black }\end{array}$ & $\begin{array}{c}\text { Share } \\
\text { SM }\end{array}$ & $\begin{array}{l}\text { Share } \\
\leq \text { HSG }\end{array}$ & $\begin{array}{l}\text { Share } \\
\text { black }\end{array}$ & $\begin{array}{c}\text { Share } \\
\text { SM }\end{array}$ & $\begin{array}{l}\text { Share } \\
\leq \text { HSG }\end{array}$ & $\begin{array}{l}\text { Share } \\
\text { black }\end{array}$ & $\begin{array}{c}\text { Share } \\
\text { SM }\end{array}$ \\
\hline & (1) & $(2)$ & (3) & (4) & (5) & (6) & $(7)$ & $(8)$ & (9) & $(10)$ & $(11)$ & $(12)$ \\
\hline Log minimum wage & $\begin{array}{c}0.0307 \\
(0.0760)\end{array}$ & $\begin{array}{l}-0.0811 \\
(0.0604)\end{array}$ & $\begin{array}{c}0.0281 \\
(0.0630)\end{array}$ & $\begin{array}{c}0.1582 * * * \\
(0.0421)\end{array}$ & $\begin{array}{c}0.1494 * * * \\
(0.0450)\end{array}$ & $\begin{array}{c}0.2420 * * * \\
(0.0434)\end{array}$ & $\begin{array}{l}-0.0534 \\
(0.1247)\end{array}$ & $\begin{array}{c}0.0147 \\
(0.0960)\end{array}$ & $\begin{array}{l}-0.0826 \\
(0.1152)\end{array}$ & $\begin{array}{l}-0.2128 \\
(0.1795)\end{array}$ & $\begin{array}{l}-0.3243 \\
(0.2555)\end{array}$ & $\begin{array}{l}-0.2889 \\
(0.1922)\end{array}$ \\
\hline $\begin{array}{l}\text { 10-year lag of log } \\
\text { minimum wage }\end{array}$ & $\begin{array}{l}-0.0267 \\
(0.0654)\end{array}$ & $\begin{array}{l}-0.0625 \\
(0.0570)\end{array}$ & $\begin{array}{l}-0.0299 \\
(0.0598)\end{array}$ & $\begin{array}{l}-0.0511 \\
(0.0509)\end{array}$ & $\begin{array}{l}-0.0299 \\
(0.0742)\end{array}$ & $\begin{array}{l}-0.0807 \\
(0.0490)\end{array}$ & $\begin{array}{l}-0.0344 \\
(0.0821)\end{array}$ & $\begin{array}{c}-0.1546 * * \\
(0.0689)\end{array}$ & $\begin{array}{l}-0.1751 \\
(0.1065)\end{array}$ & $\begin{array}{l}-0.2092 \\
(0.1355)\end{array}$ & $\begin{array}{l}-0.2858 * \\
(0.1567)\end{array}$ & $\begin{array}{c}-0.3311^{* *} \\
(0.1554)\end{array}$ \\
\hline Log EITC phase-in rate & $\begin{array}{l}0.0659 * * \\
(0.0264)\end{array}$ & $\begin{array}{l}0.0485^{* *} \\
(0.0235)\end{array}$ & $\begin{array}{c}0.0683 * * * \\
(0.0186)\end{array}$ & $\begin{array}{l}-0.0057 \\
(0.0154)\end{array}$ & $\begin{array}{l}-0.0106 \\
(0.0225)\end{array}$ & $\begin{array}{l}-0.0220 \\
(0.0145)\end{array}$ & $\begin{array}{c}-0.1131^{* * * *} \\
(0.0376)\end{array}$ & $\begin{array}{c}-0.1558 * * * \\
(0.0231)\end{array}$ & $\begin{array}{c}-0.1450^{* * *} \\
(0.0385)\end{array}$ & $\begin{array}{l}-0.0972^{*} \\
(0.0579)\end{array}$ & $\begin{array}{l}-0.1256^{*} \\
(0.0662)\end{array}$ & $\begin{array}{c}-0.1569 * * * \\
(0.0527)\end{array}$ \\
\hline $\begin{array}{l}10 \text {-year lag of log } \\
\text { EITC phase-in rate }\end{array}$ & $\begin{array}{c}-0.0271 * * \\
(0.0120)\end{array}$ & $\begin{array}{c}-0.0363 * * \\
(0.0165)\end{array}$ & $\begin{array}{l}-0.0174 \\
(0.0126)\end{array}$ & $\begin{array}{c}0.0162 * * * \\
(0.0056)\end{array}$ & $\begin{array}{c}0.0101 \\
(0.0066)\end{array}$ & $\begin{array}{c}0.0203 * * * \\
(0.0070)\end{array}$ & $\begin{array}{l}-0.0085 \\
(0.0162)\end{array}$ & $\begin{array}{c}-0.0350 * * \\
(0.0135)\end{array}$ & $\begin{array}{l}-0.0167 \\
(0.0147)\end{array}$ & $\begin{array}{c}-0.0611 * * \\
(0.0234)\end{array}$ & $\begin{array}{c}-0.0980 * * * \\
(0.0324)\end{array}$ & $\begin{array}{c}-0.0916 * * * \\
(0.0231)\end{array}$ \\
\hline $\begin{array}{l}\text { Log maximum } \\
\text { welfare benefit }\end{array}$ & $\begin{array}{c}0.1239 * * * \\
(0.0292)\end{array}$ & $\begin{array}{l}0.1184 * * \\
(0.0486)\end{array}$ & $\begin{array}{l}0.0947 * * \\
(0.0429)\end{array}$ & $\begin{array}{l}-0.0180 \\
(0.0143)\end{array}$ & $\begin{array}{c}0.0165 \\
(0.0262)\end{array}$ & $\begin{array}{c}0.0052 \\
(0.0217)\end{array}$ & $\begin{array}{l}-0.1072^{*} \\
(0.0591)\end{array}$ & $\begin{array}{c}0.0081 \\
(0.0618)\end{array}$ & $\begin{array}{c}0.0368 \\
(0.0743)\end{array}$ & $\begin{array}{l}-0.1573 * \\
(0.0827)\end{array}$ & $\begin{array}{c}0.0300 \\
(0.0917)\end{array}$ & $\begin{array}{c}0.0454 \\
(0.0784)\end{array}$ \\
\hline $\begin{array}{l}\text { 10-year lag of log } \\
\text { maximum welfare benefit }\end{array}$ & $\begin{array}{l}-0.0140 \\
(0.0130)\end{array}$ & $\begin{array}{l}-0.0097 \\
(0.0139)\end{array}$ & $\begin{array}{l}-0.0211 \\
(0.0172)\end{array}$ & $\begin{array}{l}\mathbf{0 . 0 1 6 6 * *} \\
(0.0076)\end{array}$ & $\begin{array}{l}-0.0035 \\
(0.0140)\end{array}$ & $\begin{array}{c}0.0073 \\
(0.0136)\end{array}$ & $\begin{array}{c}0.1406 * * * \\
(0.0213)\end{array}$ & $\begin{array}{c}0.1238 * * * \\
(0.0324)\end{array}$ & $\begin{array}{c}\mathbf{0 . 1 0 8 1} * * \\
(0.0457)\end{array}$ & $\begin{array}{c}0.1673 * * * \\
(0.0278)\end{array}$ & $\begin{array}{c}0.1217 * * * \\
(0.0377)\end{array}$ & $\begin{array}{c}0.1800 * * * \\
(0.0394)\end{array}$ \\
\hline $\begin{array}{l}\text { Welfare time limit } \\
<60 \text { months }\end{array}$ & $\begin{array}{l}-0.0001 \\
(0.0187)\end{array}$ & $\begin{array}{l}-0.0247 \\
(0.0325)\end{array}$ & $\begin{array}{l}-0.0066 \\
(0.0310)\end{array}$ & $\begin{array}{c}-0.0242 * * \\
(0.0110)\end{array}$ & $\begin{array}{l}-0.0216^{*} \\
(0.0111)\end{array}$ & $\begin{array}{l}-0.0167 \\
(0.0107)\end{array}$ & $\begin{array}{l}-0.0242 \\
(0.0209)\end{array}$ & $\begin{array}{l}-0.0243 \\
(0.0237)\end{array}$ & $\begin{array}{c}0.0038 \\
(0.0269)\end{array}$ & $\begin{array}{l}-0.0363 \\
(0.0271)\end{array}$ & $\begin{array}{l}0.0138 \\
(0.0318)\end{array}$ & $\begin{array}{l}0.0022 \\
(0.0291)\end{array}$ \\
\hline $\begin{array}{l}\text { 10-year lag of welfare time } \\
\text { limits }<60 \text { months }\end{array}$ & $\begin{array}{l}-0.0062 \\
(0.0244)\end{array}$ & $\begin{array}{c}0.0028 \\
(0.0288)\end{array}$ & $\begin{array}{c}0.0100 \\
(0.0315)\end{array}$ & $\begin{array}{l}-0.0117 \\
(0.0140)\end{array}$ & $\begin{array}{l}-0.0071 \\
(0.0136)\end{array}$ & $\begin{array}{c}0.0035 \\
(0.0138)\end{array}$ & $\begin{array}{l}-0.0392 \\
(0.0242)\end{array}$ & $\begin{array}{c}-0.0515^{* *} \\
(0.0196)\end{array}$ & $\begin{array}{c}-0.0637 * * \\
(0.0268)\end{array}$ & $\begin{array}{c}-0.0965 * * \\
(0.0448)\end{array}$ & $\begin{array}{l}-0.0819 \\
(0.0566)\end{array}$ & $\begin{array}{c}-0.1257 * * \\
(0.0567)\end{array}$ \\
\hline Adjusted $\mathrm{R}^{2}$ & 0.69 & 0.69 & 0.69 & 0.74 & 0.74 & 0.74 & 0.79 & 0.79 & 0.79 & 0.76 & 0.77 & 0.77 \\
\hline $\mathrm{N}$ & 206,617 & 206,675 & 206,675 & 206,776 & 206,836 & 206,836 & 206,652 & 206,710 & 206,710 & 206,617 & 206,675 & 206,675 \\
\hline Tract fixed effects & Yes & Yes & Yes & Yes & Yes & Yes & Yes & Yes & Yes & Yes & Yes & Yes \\
\hline County x year interactions & Yes & Yes & Yes & Yes & Yes & Yes & Yes & Yes & Yes & Yes & Yes & Yes \\
\hline
\end{tabular}

\footnotetext{
Notes: See notes to Tables 2. The specifications differ from those in Table 2 in the measures of disadvantage used. HSG=high school graduate. SM = single mothers.
} 
Table 4: Effects of Anti-Poverty Policies on Average Earnings per Household, Employment Rate, Share in Poverty, and Share on Public Assistance in Areas with High Share Poverty at Baseline (1970), with Migration Controls

\begin{tabular}{|c|c|c|c|c|}
\hline & $(1)$ & $(2)$ & (3) & (4) \\
\hline Outcomes & Earnings & Employment & Poverty & $\begin{array}{c}\text { Public } \\
\text { assistance }\end{array}$ \\
\hline Log minimum wage & $\begin{array}{l}0.1606^{*} \\
(0.0879)\end{array}$ & $\begin{array}{c}0.2413^{* * *} \\
(0.0518)\end{array}$ & $\begin{array}{l}-0.0468 \\
(0.1341)\end{array}$ & $\begin{array}{c}-0.3573^{* *} \\
(0.1721)\end{array}$ \\
\hline 10-year lag of log minimum wage & $\begin{array}{l}-0.0842 \\
(0.0698)\end{array}$ & $\begin{array}{l}-0.1056 \\
(0.0727)\end{array}$ & $\begin{array}{c}-0.1593^{*} \\
(0.0839)\end{array}$ & $\begin{array}{c}-0.3731 * * \\
(0.1570)\end{array}$ \\
\hline Log EITC phase-in rate & $\begin{array}{l}0.0507^{*} \\
(0.0266)\end{array}$ & $\begin{array}{l}-0.0200 \\
(0.0194)\end{array}$ & $\begin{array}{c}-0.2121 * * * \\
(0.0313)\end{array}$ & $\begin{array}{c}-0.1797 * * * \\
(0.0504)\end{array}$ \\
\hline 10-year lag of log EITC phase-in rate & $\begin{array}{c}0.0101 \\
(0.0110)\end{array}$ & $\begin{array}{c}0.0254 * * * \\
(0.0064)\end{array}$ & $\begin{array}{c}-0.0432 * * * \\
(0.0151)\end{array}$ & $\begin{array}{c}-0.1010 * * * \\
(0.0210)\end{array}$ \\
\hline Log maximum welfare benefit & $\begin{array}{c}0.0354 \\
(0.0341)\end{array}$ & $\begin{array}{l}-0.0043 \\
(0.0204)\end{array}$ & $\begin{array}{c}0.0274 \\
(0.0694)\end{array}$ & $\begin{array}{c}0.0316 \\
(0.0730)\end{array}$ \\
\hline 10-year lag of log maximum welfare benefit & $\begin{array}{l}-0.0080 \\
(0.0170)\end{array}$ & $\begin{array}{c}0.0001 \\
(0.0115)\end{array}$ & $\begin{array}{l}0.1676 * * * \\
(0.0306)\end{array}$ & $\begin{array}{c}0.1423 * * * \\
(0.0373)\end{array}$ \\
\hline Welfare time limits (<60 months) & $\begin{array}{l}-0.0066 \\
(0.0227)\end{array}$ & $\begin{array}{c}-0.0287^{* *} \\
(0.0111)\end{array}$ & $\begin{array}{l}-0.0245 \\
(0.0249)\end{array}$ & $\begin{array}{c}0.0102 \\
(0.0282)\end{array}$ \\
\hline 10-year lag of welfare time limits ( $<60$ months) & $\begin{array}{l}-0.0157 \\
(0.0248)\end{array}$ & $\begin{array}{l}-0.0163 \\
(0.0137)\end{array}$ & $\begin{array}{c}-0.0784 * * * \\
(0.0273)\end{array}$ & $\begin{array}{l}-0.0901 * \\
(0.0461)\end{array}$ \\
\hline Proportion moved from within county & $\begin{array}{c}-0.3640 * * * \\
(0.0721)\end{array}$ & $\begin{array}{l}0.0846 * * \\
(0.0327)\end{array}$ & $\begin{array}{c}0.6772 * * * \\
(0.0385)\end{array}$ & $\begin{array}{c}0.2455 * * * \\
(0.0353)\end{array}$ \\
\hline Proportion moved from somewhere else & $\begin{array}{c}0.2078 * * * \\
(0.0487)\end{array}$ & $\begin{array}{c}0.0315 \\
(0.0194)\end{array}$ & $\begin{array}{l}0.1329 * \\
(0.0745)\end{array}$ & $\begin{array}{c}-0.6933 * * * \\
(0.0923)\end{array}$ \\
\hline Adjusted $\mathrm{R}^{2}$ & 0.83 & 0.78 & 0.84 & 0.79 \\
\hline $\mathrm{N}$ & 206,404 & 206,470 & 206,422 & 206,404 \\
\hline Tract fixed effects & Yes & Yes & Yes & Yes \\
\hline County $\mathrm{x}$ year interactions & Yes & Yes & Yes & Yes \\
\hline
\end{tabular}

Notes: See notes to Table 2. The only difference is the addition of migration controls. 
Table 5: Effects of Anti-Poverty Policies on Average Earnings per Household, Employment Rate, Share in Poverty, and Share on Public Assistance in Areas with High Poverty Rate at Baseline (1970), 1980-2010, Omitting 3rd Quartile of Disadvantage

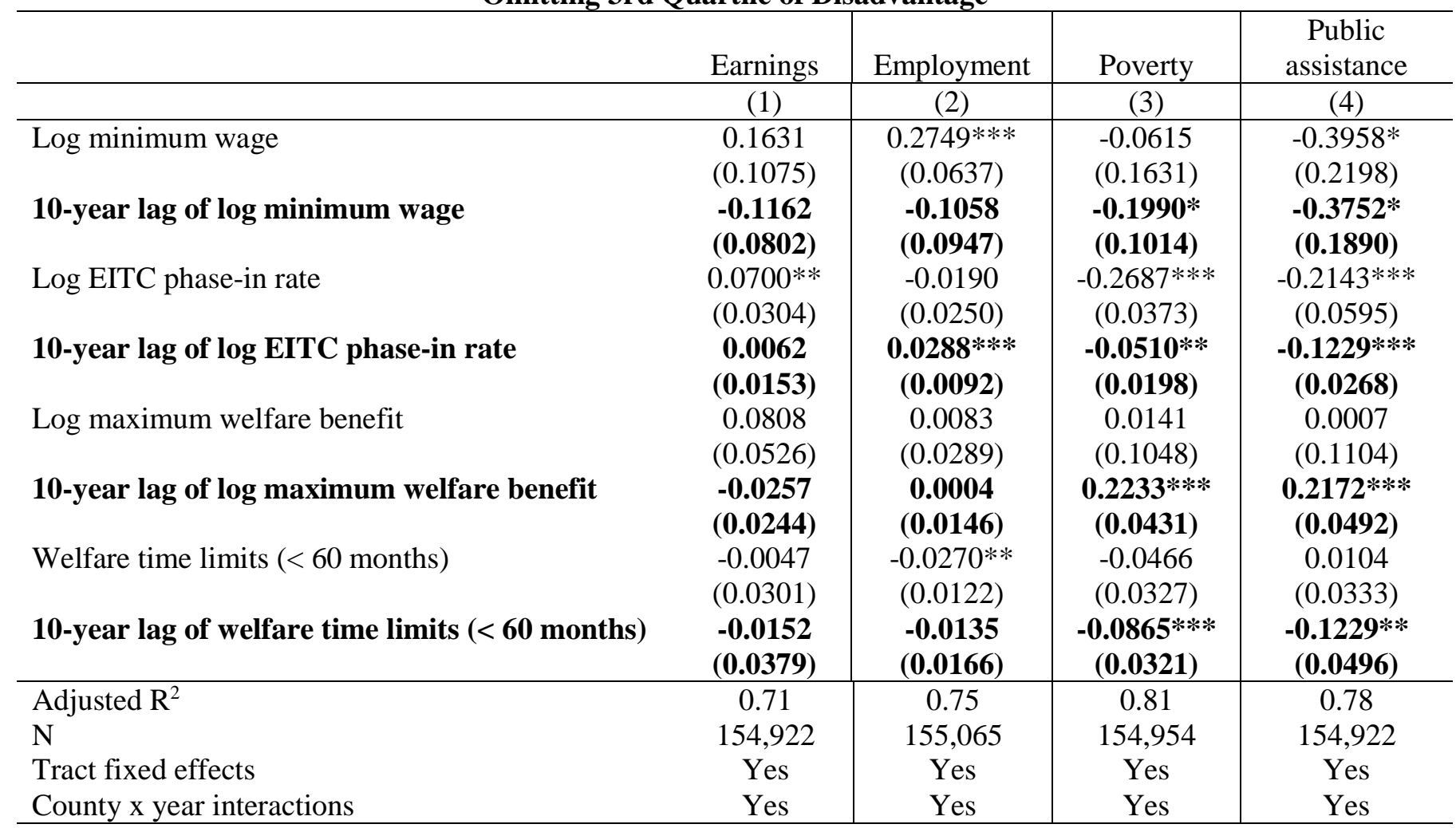

Notes: See notes to Table 2. The only difference is omitting the third quartile of the disadvantage measure. 
Table 6: Effects of Anti-Poverty Policies on Average Earnings per Household, Employment Rate, Share in Poverty, and Share on Public Assistance in Areas with High Poverty Rate at Baseline (1970), 1980-2010, Top vs. Third Quartile

\begin{tabular}{|c|c|c|c|c|}
\hline & Earnings & Employment & Poverty & $\begin{array}{c}\text { Public } \\
\text { Assistance }\end{array}$ \\
\hline & (1) & (2) & $(5)$ & $(6)$ \\
\hline Log minimum wage & $\begin{array}{c}0.1176 \\
(0.0704)\end{array}$ & $\begin{array}{c}0.1870 * * * \\
(0.0420)\end{array}$ & $\begin{array}{c}0.0088 \\
(0.0734)\end{array}$ & $\begin{array}{c}-0.1133 \\
(0.0936)\end{array}$ \\
\hline 10-year lag of log minimum wage & $\begin{array}{c}-0.0533 \\
(0.0526)\end{array}$ & $\begin{array}{c}-0.0606 \\
(0.0610)\end{array}$ & $\begin{array}{c}-0.1412^{* *} \\
(0.0689)\end{array}$ & $\begin{array}{c}-0.3444^{* *} \\
(0.1433)\end{array}$ \\
\hline Log EITC phase-in rate & $\begin{array}{l}0.0388 * \\
(0.0216)\end{array}$ & $\begin{array}{l}-0.0063 \\
(0.0156)\end{array}$ & $\begin{array}{c}-0.1478 * * * \\
(0.0219)\end{array}$ & $\begin{array}{c}-0.1749 * * * \\
(0.0416)\end{array}$ \\
\hline 10-year lag of log EITC phase-in rate & $\begin{array}{c}0.0074 \\
(0.0074)\end{array}$ & $\begin{array}{c}0.0178 * * * \\
(0.0045)\end{array}$ & $\begin{array}{c}-0.0221 * * \\
(0.0098)\end{array}$ & $\begin{array}{c}-0.0602^{* * *} * \\
(0.0144)\end{array}$ \\
\hline Log maximum welfare benefit & $\begin{array}{c}0.0061 \\
(0.0237)\end{array}$ & $\begin{array}{l}-0.0090 \\
(0.0162)\end{array}$ & $\begin{array}{c}0.0298 \\
(0.0630)\end{array}$ & $\begin{array}{c}0.0288 \\
(0.0711)\end{array}$ \\
\hline 10-year lag of log maximum welfare benefit & $\begin{array}{c}-0.0046 \\
(0.0135)\end{array}$ & $\begin{array}{l}-0.0013 \\
(0.0094)\end{array}$ & $\begin{array}{c}0.0861 * * * \\
(0.0286)\end{array}$ & $\begin{array}{c}0.1041 * * * \\
(0.0338)\end{array}$ \\
\hline Welfare time limits ( $<60$ months) & $\begin{array}{c}0.0043 \\
(0.0131)\end{array}$ & $\begin{array}{c}-0.0270^{* * *} \\
(0.0120)\end{array}$ & $\begin{array}{l}-0.0167 \\
(0.0178)\end{array}$ & $\begin{array}{l}-0.0223 \\
(0.0257)\end{array}$ \\
\hline 10-year lag of welfare time limits ( $<60$ months) & $\begin{array}{c}-0.0036 \\
(0.0152) \\
\end{array}$ & $\begin{array}{c}-0.0138 \\
(0.0103) \\
\end{array}$ & $\begin{array}{c}-0.0757^{* * *} * \\
(0.0199) \\
\end{array}$ & $\begin{array}{c}-0.0735^{*} \\
(0.0413) \\
\end{array}$ \\
\hline $\begin{array}{l}\text { Adjusted } \mathrm{R}^{2} \\
\mathrm{~N} \\
\text { Tract fixed effects } \\
\text { County x year interactions }\end{array}$ & $\begin{array}{c}0.65 \\
103,444 \\
\text { Yes } \\
\text { Yes }\end{array}$ & $\begin{array}{c}0.7 \\
103,488 \\
\text { Yes } \\
\text { Yes }\end{array}$ & $\begin{array}{c}0.79 \\
103,451 \\
\text { Yes } \\
\text { Yes }\end{array}$ & $\begin{array}{c}0.79 \\
103,444 \\
\text { Yes } \\
\text { Yes }\end{array}$ \\
\hline
\end{tabular}

Notes: See notes to Table 2 . The only difference is that the $1^{\text {st }}$ and $2^{\text {nd }}$ quartiles of the disadvantage measure are omitted. 
Table 7: Effects of Anti-Poverty Policies on Average Earnings per Household, Employment Rate, Share in Poverty, and Share on Public Assistance in Areas with High Poverty Rate at Baseline (1980), 1990-2010

\begin{tabular}{lc|c|c|c}
\hline & Earnings & Employment & Poverty & $\begin{array}{c}\text { Public } \\
\text { assistance }\end{array}$ \\
\hline & $(1)$ & $(2)$ & $(3)$ & $(4)$ \\
\hline Log minimum wage & 0.0955 & 0.0704 & 0.0632 & 0.3124 \\
& $(0.1527)$ & $(0.0917)$ & $(0.3045)$ & $(0.5551)$ \\
10-year lag of log minimum wage & $\mathbf{- 0 . 1 0 4 5}$ & $\mathbf{- 0 . 1 0 4 5}$ & $\mathbf{0 . 2 0 6 4}$ & $\mathbf{0 . 3 9 8 6}$ \\
& $\mathbf{( 0 . 1 0 4 6 )}$ & $\mathbf{( 0 . 0 7 1 8 )}$ & $\mathbf{( 0 . 1 3 8 8 )}$ & $\mathbf{( 0 . 2 6 5 3 )}$ \\
Log EITC phase-in rate & -0.0068 & -0.0191 & 0.0057 & 0.1029 \\
& $(0.0316)$ & $(0.0213)$ & $(0.0393)$ & $(0.0819)$ \\
10-year lag of log EITC phase-in rate & $\mathbf{- 0 . 0 2 2 9}$ & $\mathbf{0 . 0 2 6 7 * * *}$ & $\mathbf{- 0 . 0 9 2 7 * * *}$ & $\mathbf{- 0 . 2 2 1 6 * * *}$ \\
& $\mathbf{( 0 . 0 1 7 0 )}$ & $\mathbf{( 0 . 0 0 9 9 )}$ & $\mathbf{( 0 . 0 2 2 5 )}$ & $\mathbf{( 0 . 0 6 1 9 )}$ \\
Log maximum welfare benefit & $0.1392 * *$ & 0.0624 & $-0.2085 * *$ & $-0.4149 * *$ \\
& $(0.0525)$ & $(0.0454)$ & $(0.0882)$ & $\mathbf{( 0 . 1 7 9 0 )}$ \\
10-year lag of log maximum welfare benefit & $\mathbf{0 . 0 8 8 3 * *}$ & $\mathbf{- 0 . 0 2 0 7}$ & $\mathbf{- 0 . 0 5 9 1}$ & $\mathbf{- 0 . 1 4 0 8}$ \\
& $\mathbf{( 0 . 0 4 1 9 )}$ & $\mathbf{( 0 . 0 3 5 4 )}$ & $\mathbf{( 0 . 0 6 3 6 )}$ & $\mathbf{( 0 . 1 0 5 4 )}$ \\
Welfare time limits (<60 months) & 0.0013 & $-0.0241 *$ & -0.0119 & -0.0233 \\
& $(0.0251)$ & $(0.0135)$ & $(0.0215)$ & $(0.0243)$ \\
10-year lag of welfare time limits (< 60 months) & $\mathbf{- 0 . 0 0 6 4}$ & $\mathbf{- 0 . 0 1 1 5}$ & $\mathbf{- 0 . 0 5 7 8 * *}$ & $\mathbf{- 0 . 1 2 7 4 * *}$ \\
& $\mathbf{( 0 . 0 2 7 5 )}$ & $\mathbf{( 0 . 0 1 4 2 )}$ & $\mathbf{( 0 . 0 2 6 9 )}$ & $\mathbf{( 0 . 0 5 1 3 )}$ \\
\hline Adjusted $\mathrm{R}^{2}$ & 0.68 & 0.75 & 0.81 & 0.76 \\
$\mathrm{~N}$ & 175,098 & 175,232 & 175,129 & 175,098 \\
Tract fixed effects & Yes & Yes & Yes & Yes \\
County x year interactions & Yes & Yes & Yes & Yes \\
\hline
\end{tabular}

Notes: See notes to Table 2. The only difference is the sample period, and the baseline year for defining disadvantage. 
Table 8: Effects of Anti-Poverty Policies on Average Earnings per Household, Employment Rate, Share in Poverty, and Share on Public Assistance in Areas with High Poverty Rate (10 Years Prior), 1980-2010

\begin{tabular}{|c|c|c|c|c|}
\hline & Earnings & Employment & Poverty & $\begin{array}{c}\text { Public } \\
\text { assistance }\end{array}$ \\
\hline & $(1)$ & $(2)$ & $(3)$ & $(4)$ \\
\hline Log minimum wage & $\begin{array}{c}-0.1104 \\
(0.0662)\end{array}$ & $\begin{array}{c}0.1861 * * * \\
(0.0544)\end{array}$ & $\begin{array}{c}-0.0206 \\
(0.1304)\end{array}$ & $\begin{array}{c}-0.3688 \\
(0.2540)\end{array}$ \\
\hline 10-year lag of log minimum wage & $\begin{array}{c}-0.1390 * * * \\
(0.0374)\end{array}$ & $\begin{array}{c}-0.1423 * * * \\
(0.0339)\end{array}$ & $\begin{array}{c}0.2055^{* * * *} \\
(0.0707)\end{array}$ & $\begin{array}{c}0.1728 \\
(0.1276)\end{array}$ \\
\hline Log EITC phase-in rate & $\begin{array}{c}0.0488^{* *} \\
(0.0234)\end{array}$ & $\begin{array}{c}-0.0466^{* *} \\
(0.0180)\end{array}$ & $\begin{array}{l}-0.0477 \\
(0.0358)\end{array}$ & $\begin{array}{c}0.0094 \\
(0.0738)\end{array}$ \\
\hline 10-year lag of log EITC phase-in rate & $\begin{array}{c}-0.0336 * * * \\
(0.0119)\end{array}$ & $\begin{array}{c}0.0227 * * \\
(0.0091)\end{array}$ & $\begin{array}{l}-0.0079 \\
(0.0209)\end{array}$ & $\begin{array}{c}-0.1063^{* *} \\
(0.0405)\end{array}$ \\
\hline Log maximum welfare benefit & $\begin{array}{c}0.0467 * * \\
(0.0220)\end{array}$ & $\begin{array}{l}-0.0090 \\
(0.0106)\end{array}$ & $\begin{array}{c}-0.0913 * * * \\
(0.0235)\end{array}$ & $\begin{array}{c}-0.0074 \\
(0.0344)\end{array}$ \\
\hline 10-year lag of log maximum welfare benefit & $\begin{array}{c}0.0150 \\
(0.0177)\end{array}$ & $\begin{array}{c}0.0079 \\
(0.0146)\end{array}$ & $\begin{array}{c}0.0770 * * * \\
(0.0248)\end{array}$ & $\begin{array}{c}0.1330 * * * \\
(0.0353)\end{array}$ \\
\hline Welfare time limits (<60 months) & $\begin{array}{c}-0.0084 \\
(0.0292)\end{array}$ & $\begin{array}{c}-0.0352^{* *} \\
(0.0152)\end{array}$ & $\begin{array}{c}0.0343 \\
(0.0277)\end{array}$ & $\begin{array}{c}0.0234 \\
(0.0188)\end{array}$ \\
\hline 10-year lag of welfare time limits ( $<60$ months) & $\begin{array}{l}-0.0091 \\
(0.0256)\end{array}$ & $\begin{array}{l}-0.0033 \\
(0.0178)\end{array}$ & $\begin{array}{c}-0.0734^{* * *} \\
(0.0274)\end{array}$ & $\begin{array}{c}-0.2091^{* * *} \\
(0.0518)\end{array}$ \\
\hline Adjusted $\mathrm{R}^{2}$ & 0.68 & 0.74 & 0.79 & 0.76 \\
\hline $\mathrm{N}$ & 226,747 & 226,893 & 226,787 & 226,747 \\
\hline Tract fixed effects & Yes & Yes & Yes & Yes \\
\hline County x year interactions & Yes & Yes & Yes & Yes \\
\hline
\end{tabular}

Notes: See notes to Table 2. The only difference is that the "baseline" disadvantage dummy variable DIS ${ }^{b}$ is defined as of 10 years prior to the observation rather than in a fixed baseline year (1970 in most of our analyses) - i.e., $D I S_{c, t-10}$ instead of $D I S^{b}$. 
Table 9: Effects of Anti-Poverty Policies on Average Earnings per Household, Employment Rate, Share in Poverty, and Share on Public Assistance in Areas with High Poverty Rate at Baseline (1970), 1980-2010, with 10-year Policy Leads

\begin{tabular}{|c|c|c|c|c|}
\hline & Earnings & Employment & Poverty & $\begin{array}{c}\text { Public } \\
\text { assistance }\end{array}$ \\
\hline & $(1)$ & $(2)$ & (3) & $(4)$ \\
\hline 10-year lead of log minimum wage & $\begin{array}{c}0.0851 \\
(0.0820)\end{array}$ & $\begin{array}{c}0.0161 \\
(0.0527)\end{array}$ & $\begin{array}{c}-0.0419 \\
(0.1531)\end{array}$ & $\begin{array}{c}0.1597 \\
(0.1489)\end{array}$ \\
\hline Log minimum wage & $\begin{array}{l}0.1240 * \\
(0.0688)\end{array}$ & $\begin{array}{c}0.2433 * * * \\
(0.0458)\end{array}$ & $\begin{array}{c}0.0347 \\
(0.1049)\end{array}$ & $\begin{array}{c}-0.2133 \\
(0.1350)\end{array}$ \\
\hline 10-year lag of log minimum wage & $\begin{array}{c}-0.1473 \\
(0.0931)\end{array}$ & $\begin{array}{c}-0.1146 \\
(0.0780)\end{array}$ & $\begin{array}{c}0.1618 \\
(0.0995)\end{array}$ & $\begin{array}{c}0.0339 \\
(0.1545)\end{array}$ \\
\hline 10-year lead of log EITC phase-in rate & $\begin{array}{l}-0.0430 \\
(0.0373)\end{array}$ & $\begin{array}{c}0.0134 \\
(0.0166)\end{array}$ & $\begin{array}{c}0.2507 * * * \\
(0.0590)\end{array}$ & $\begin{array}{c}0.3500 * * * \\
(0.0751)\end{array}$ \\
\hline Log EITC phase-in rate & $\begin{array}{c}0.0368 \\
(0.0340)\end{array}$ & $\begin{array}{l}-0.0219 \\
(0.0211)\end{array}$ & $\begin{array}{c}-0.0958 * * \\
(0.0380)\end{array}$ & $\begin{array}{c}-0.0246 \\
(0.0571)\end{array}$ \\
\hline 10-year lag of log EITC phase-in rate & $\begin{array}{c}0.0164 \\
(0.0160)\end{array}$ & $\begin{array}{c}0.0193 * * * \\
(0.0054)\end{array}$ & $\begin{array}{c}-0.1065^{* * *} \\
(0.0221)\end{array}$ & $\begin{array}{c}-0.2166 * * * \\
(0.0317)\end{array}$ \\
\hline 10-year lead of log maximum welfare benefit & $\begin{array}{l}-0.0097 \\
(0.0401)\end{array}$ & $\begin{array}{c}0.0188 \\
(0.0280)\end{array}$ & $\begin{array}{l}-0.1264 * \\
(0.0734)\end{array}$ & $\begin{array}{c}-0.2090 * * * \\
(0.0680)\end{array}$ \\
\hline Log maximum welfare benefit & $\begin{array}{c}0.0574 \\
(0.0379)\end{array}$ & $\begin{array}{l}-0.0083 \\
(0.0245)\end{array}$ & $\begin{array}{l}-0.0315 \\
(0.0630)\end{array}$ & $\begin{array}{c}-0.0344 \\
(0.0709)\end{array}$ \\
\hline 10-year lag of log maximum welfare benefit & $\begin{array}{c}-0.0067 \\
(0.0226)\end{array}$ & $\begin{array}{c}-0.0009 \\
(0.0124)\end{array}$ & $\begin{array}{c}0.0950 * * * \\
(0.0315)\end{array}$ & $\begin{array}{c}0.0601 \\
(0.0372)\end{array}$ \\
\hline 10-year lead of welfare time limits ( $<60$ months) & $\begin{array}{l}-0.0131 \\
(0.0124)\end{array}$ & $\begin{array}{c}0.0112 \\
(0.0097)\end{array}$ & $\begin{array}{c}-0.0362^{*} \\
(0.0211)\end{array}$ & $\begin{array}{l}-0.0099 \\
(0.0272)\end{array}$ \\
\hline Welfare time limits ( $<60$ months) & $\begin{array}{c}-0.0093 \\
(0.0251)\end{array}$ & $\begin{array}{c}-0.0312 * * \\
(0.0119)\end{array}$ & $\begin{array}{c}0.0007 \\
(0.0222)\end{array}$ & $\begin{array}{c}0.0184 \\
(0.0309)\end{array}$ \\
\hline 10-year lag of welfare time limits ( $<60$ months) & $\begin{array}{c}-0.0192 \\
(0.0294) \\
\end{array}$ & $\begin{array}{c}-0.0102 \\
(0.0139) \\
\end{array}$ & $\begin{array}{c}-0.0512 * \\
(0.0290)\end{array}$ & $\begin{array}{c}-0.0530 \\
(0.0419) \\
\end{array}$ \\
\hline Adjusted $\mathrm{R}^{2}$ & 0.69 & 0.74 & 0.79 & 0.77 \\
\hline & 206,675 & 206,836 & 206,710 & 206,675 \\
\hline Tract fixed effects & Yes & Yes & Yes & Yes \\
\hline County x year interactions & Yes & Yes & Yes & Yes \\
\hline
\end{tabular}

Notes: See notes to Table 2 . The only difference is the addition of 10-year leads of the policy variables. 
Appendix Table A1: Effects of Anti-Poverty Policies on Male and Female Employment Rates in Areas with High Poverty Rate at Baseline (1970), 19802010

\begin{tabular}{l|c|c}
\hline & $\begin{array}{c}\text { Male } \\
\text { employment }\end{array}$ & $\begin{array}{c}\text { Female } \\
\text { employment }\end{array}$ \\
\hline Log minimum wage & $(1)$ & $(2)$ \\
10-year lag of log minimum wage & $0.1800^{* * *}$ & $0.2647 * * *$ \\
& $(0.0555)$ & $(0.0585)$ \\
Log EITC phase-in rate & $\mathbf{- 0 . 0 0 8 4}$ & $\mathbf{- 0 . 1 3 6 6}$ \\
& $\mathbf{( 0 . 0 5 3 7 )}$ & $\mathbf{( 0 . 0 8 7 5 )}$ \\
10-year lag of log EITC phase-in rate & -0.0062 & -0.0138 \\
& $(0.0169)$ & $(0.0222)$ \\
Log maximum welfare benefit & $\mathbf{0 . 0 1 8 9 * *}$ & $\mathbf{0 . 0 2 4 6} * * *$ \\
& $\mathbf{( 0 . 0 0 8 4 )}$ & $\mathbf{( 0 . 0 0 6 4 )}$ \\
10-year lag of log maximum welfare benefit & -0.0001 & 0.0112 \\
& $(0.0185)$ & $(0.0222)$ \\
Welfare time limits (<60 months) & $\mathbf{0 . 0 1 1 2}$ & $\mathbf{- 0 . 0 1 7 4}$ \\
& $\mathbf{( 0 . 0 1 1 2 )}$ & $\mathbf{( 0 . 0 1 3 3 )}$ \\
10-year lag of welfare time limits (<6 months) & $-0.0237 * *$ & $-0.0334^{* * *}$ \\
& $(0.0114)$ & $(0.0123)$ \\
\hline Adjusted $\mathrm{R}^{2}$ & $\mathbf{- 0 . 0 2 5 1 *}$ & $\mathbf{0 . 0 0 0 8}$ \\
N & $\mathbf{( 0 . 0 1 4 7 )}$ & $\mathbf{( 0 . 0 1 4 9 )}$ \\
Tract fixed effects & 0.71 & 0.66 \\
County x year interactions & 206,823 & 206,791 \\
\hline Not & Yes & Yes \\
& Yes & Yes \\
\hline
\end{tabular}

Notes: See notes to Table 2. The only difference is the dependent variables. 
Appendix Table A2: Effects of Anti-Poverty Policies on Average Earnings per Household, Employment Rate, Share in Poverty, and Share on Public Assistance in Areas with High Poverty Rate at Baseline (1970), 1980-2010, One Policy at a Time

\begin{tabular}{|c|c|c|c|c|}
\hline & Earnings & Employment & Poverty & $\begin{array}{c}\text { Public } \\
\text { assistance }\end{array}$ \\
\hline & $(1)$ & $(2)$ & (3) & (4) \\
\hline \multicolumn{5}{|l|}{ I. Minimum wages } \\
\hline Log minimum wage & $\begin{array}{c}0.1505 * * * \\
(0.0473)\end{array}$ & $\begin{array}{c}0.0955^{* * *} \\
(0.0271)\end{array}$ & $\begin{array}{c}-0.2120 * * * \\
(0.0713)\end{array}$ & $\begin{array}{c}-0.2133 * * \\
(0.0960)\end{array}$ \\
\hline 10-year lag of log minimum wage & $\begin{array}{c}-0.3381 * * * \\
(0.0311)\end{array}$ & $\begin{array}{c}-0.1353 * * * \\
(0.0266) \\
\end{array}$ & $\begin{array}{c}0.5672 * * * \\
(0.0303)\end{array}$ & $\begin{array}{c}0.6021 * * * \\
(0.0527)\end{array}$ \\
\hline \multicolumn{5}{|l|}{ II. EITC } \\
\hline Log EITC phase-in rate & $\begin{array}{c}0.0926 * * * \\
(0.0126)\end{array}$ & $\begin{array}{c}0.0229 * * * \\
(0.0080)\end{array}$ & $\begin{array}{c}-0.1430 * * * \\
(0.0091)\end{array}$ & $\begin{array}{c}-0.1113^{* * *} \\
(0.0124)\end{array}$ \\
\hline 10-year lag of log EITC phase-in rate & $\begin{array}{l}-0.0030 \\
(0.0051)\end{array}$ & $\begin{array}{c}0.0031 \\
(0.0044)\end{array}$ & $\begin{array}{l}-0.0110 \\
(0.0068)\end{array}$ & $\begin{array}{c}-0.0459 * * * \\
(0.0057)\end{array}$ \\
\hline \multicolumn{5}{|l|}{ III. Welfare } \\
\hline Log maximum welfare benefit & $\begin{array}{c}0.0964 * * * \\
(0.0316)\end{array}$ & $\begin{array}{c}0.0261 \\
(0.0192)\end{array}$ & $\begin{array}{c}-0.2302^{* *} \\
(0.1048)\end{array}$ & $\begin{array}{c}-0.3222^{* * *} \\
(0.0989)\end{array}$ \\
\hline 10-year lag of log maximum welfare benefit & $\begin{array}{c}0.0635 * * * \\
(0.0162)\end{array}$ & $\begin{array}{c}0.0289 * * * \\
(0.0094)\end{array}$ & $\begin{array}{c}-\mathbf{0 . 0 5 6 1 * *} \\
(0.0267)\end{array}$ & $\begin{array}{c}-0.0756 * * \\
(0.0300)\end{array}$ \\
\hline Welfare time limits (<60 months) & $\begin{array}{c}0.0361^{* *} \\
(0.0175)\end{array}$ & $\begin{array}{l}-0.0171 \\
(0.0119)\end{array}$ & $\begin{array}{c}-0.0844 * * * \\
(0.0271)\end{array}$ & $\begin{array}{l}-0.0295 \\
(0.0318)\end{array}$ \\
\hline 10-year lag of welfare time limits ( $<60$ months) & $\begin{array}{c}-\mathbf{0 . 0 0 0 4} \\
(\mathbf{0 . 0 1 7 3 )}\end{array}$ & $\begin{array}{c}0.0094 \\
(0.0084)\end{array}$ & $\begin{array}{c}-0.1458 * * * \\
(0.0277)\end{array}$ & $\begin{array}{c}-0.2399 * * * \\
(0.0383)\end{array}$ \\
\hline Adjusted $\mathrm{R}^{2}$ & 0.69 & 0.74 & 0.79 & 0.77 \\
\hline $\mathrm{N}$ & 206,675 & 206,836 & 206,710 & 206,675 \\
\hline Tract fixed effects & Yes & Yes & Yes & Yes \\
\hline County x year interactions & Yes & Yes & Yes & Yes \\
\hline
\end{tabular}

Notes: See notes to Table 2. The difference in this table is that each panel reports estimates of the specification using minimum wage, EITC, and welfare variables separately, rather than simultaneously. 
Appendix Table A3: Effects of Anti-Poverty Policies on Average Earnings per Household, Employment Rate, Share in Poverty, and Share on Public Assistance in Areas with High Poverty Rate at Baseline (1970), 1980-2010, Saturated Model Absorbing Federal Variation Across Disadvantaged vs. Advantaged Tracts

\begin{tabular}{|c|c|c|c|c|}
\hline & Earnings & Employment & Poverty & $\begin{array}{c}\text { Public } \\
\text { assistance }\end{array}$ \\
\hline & $(1)$ & $(2)$ & $(3)$ & $(4)$ \\
\hline Log minimum wage & $\begin{array}{c}0.0745 \\
(0.0968)\end{array}$ & $\begin{array}{c}0.2223 * * * \\
(0.0789)\end{array}$ & $\begin{array}{c}0.3598^{* *} \\
(0.1563)\end{array}$ & $\begin{array}{c}0.2552 \\
(0.1980)\end{array}$ \\
\hline 10-year lag of log minimum wage & $\begin{array}{c}-0.1598 * * \\
(0.0782)\end{array}$ & $\begin{array}{l}-0.0960 \\
(0.0766)\end{array}$ & $\begin{array}{c}0.3478 * * * \\
(0.0952)\end{array}$ & $\begin{array}{c}\text { 0.3161** } \\
(0.1294)\end{array}$ \\
\hline Log EITC phase-in rate & $\begin{array}{l}-0.1003 \\
(0.0989)\end{array}$ & $\begin{array}{c}-0.0494 \\
(0.0449)\end{array}$ & $\begin{array}{l}-0.1924 \\
(0.1312)\end{array}$ & $\begin{array}{l}-0.0100 \\
(0.1792)\end{array}$ \\
\hline 10-year lag of log EITC phase-in rate & $\begin{array}{c}-0.0326 \\
(0.1559)\end{array}$ & $\begin{array}{c}0.0404 \\
(0.0567)\end{array}$ & $\begin{array}{c}0.2063 \\
(0.2410)\end{array}$ & $\begin{array}{c}0.3811 \\
(0.3237)\end{array}$ \\
\hline Log maximum welfare benefit & $\begin{array}{l}0.0642 * \\
(0.0376)\end{array}$ & $\begin{array}{l}-0.0022 \\
(0.0193)\end{array}$ & $\begin{array}{c}-0.1221^{* * * *} \\
(0.0453)\end{array}$ & $\begin{array}{c}-0.1714^{* *} \\
(0.0643)\end{array}$ \\
\hline 10-year lag of log maximum welfare benefit & $\begin{array}{c}0.0018 \\
(0.0240)\end{array}$ & $\begin{array}{c}0.0017 \\
(0.0139)\end{array}$ & $\begin{array}{c}0.0826 * * * \\
(0.0255)\end{array}$ & $\begin{array}{c}0.0492 \\
(0.0340)\end{array}$ \\
\hline Welfare time limits (<60 months) & $\begin{array}{l}-0.0104 \\
(0.0226)\end{array}$ & $\begin{array}{c}-0.0290^{* *} \\
(0.0112)\end{array}$ & $\begin{array}{c}-0.0166 \\
(0.0221)\end{array}$ & $\begin{array}{c}0.0194 \\
(0.0230)\end{array}$ \\
\hline 10-year lag of welfare time limits ( $<60$ months) & $\begin{array}{c}-0.0212 \\
(0.0280) \\
\end{array}$ & $\begin{array}{c}-0.0166 \\
(0.0140) \\
\end{array}$ & $\begin{array}{c}-0.0521 \\
(0.0329) \\
\end{array}$ & $\begin{array}{c}-0.0553 \\
(\mathbf{0 . 0 5 7 1}) \\
\end{array}$ \\
\hline $\begin{array}{l}\text { Adjusted } \mathrm{R}^{2} \\
\mathrm{~N} \\
\text { Tract fixed effects } \\
\text { County x year interactions }\end{array}$ & $\begin{array}{c}0.69 \\
206,675 \\
\text { Yes } \\
\text { Yes }\end{array}$ & $\begin{array}{c}0.74 \\
206,836 \\
\text { Yes } \\
\text { Yes }\end{array}$ & $\begin{array}{c}0.79 \\
206,710 \\
\text { Yes } \\
\text { Yes }\end{array}$ & $\begin{array}{c}0.77 \\
206,675 \\
\text { Yes } \\
\text { Yes }\end{array}$ \\
\hline
\end{tabular}

Notes: See notes to Table 2 . The only difference is the inclusion of the $D I S^{b} \cdot Y R$ interactions. 
Appendix Table A4: Effects of Anti-Poverty Policies on Average Earnings per Household, Employment Rate, Share in Poverty, and Share on Public Assistance in Areas with High Share Poverty at Baseline (1970), Separate Effects of Welfare Benefits Post-Welfare Reform, 1980-2010

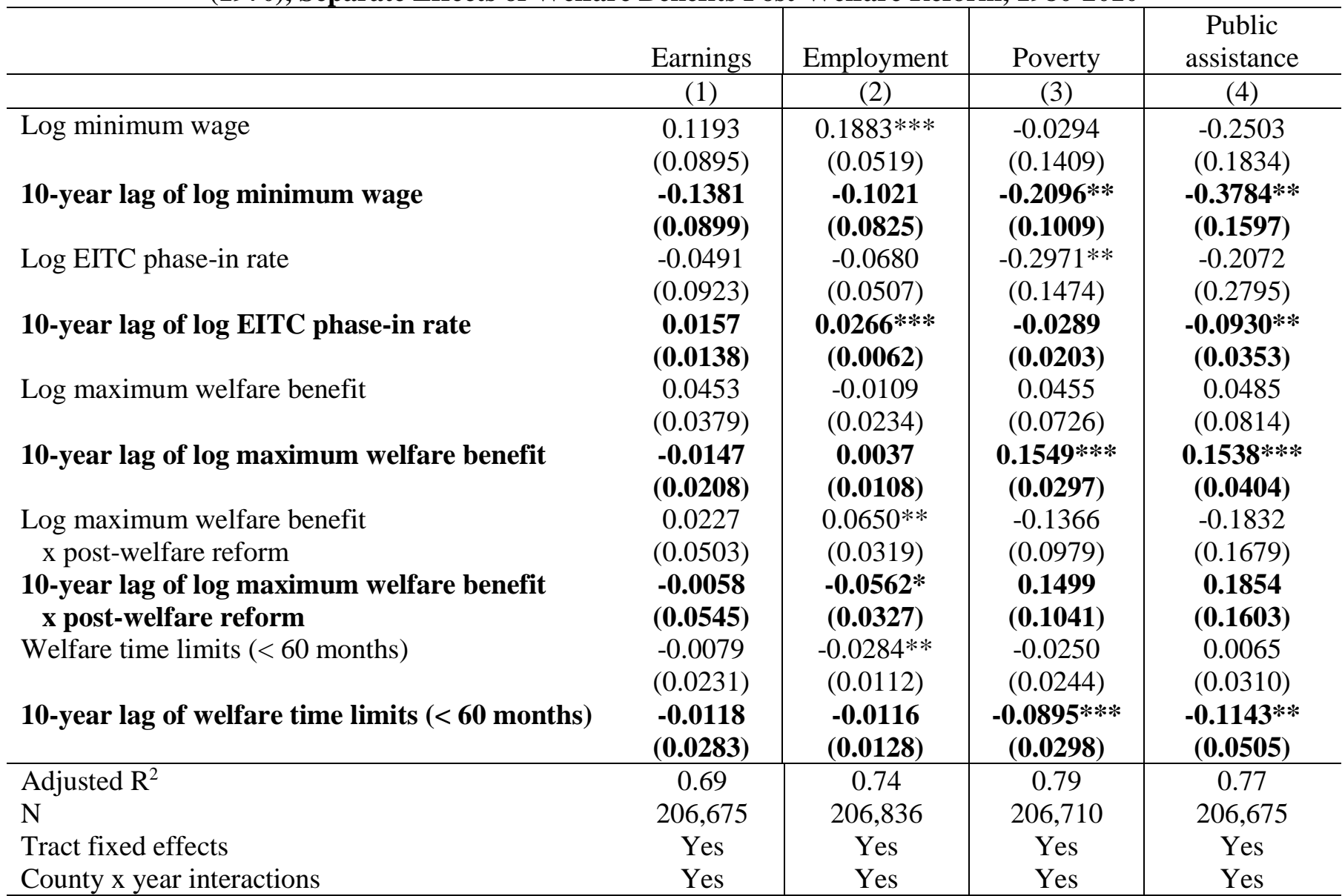

Notes: See notes to Table 2. The only difference is the additional set of welfare benefit variables interacted with the postwelfare reform (year > 1996) variable. 